\title{
Malvoideae Burnett (Malvaceae) in the Environmental Protection Area Serra Branca, Raso da Catarina, Jeremoabo, Bahia, Brazil
}

\author{
Jéssica Batista Lima \& Adilva de Souza Conceição* \\ Universidade do Estado da Bahia, Departamento de Educacão, Herbário HUNEB (Coleção Paulo Afonso), \\ Campus VIII, Paulo Afonso, BA, Brazil. \\ *Corresponding author: Adilva de Souza Conceição,e-mail: adilva.souza@gmail.com
}

LIMA, J.B., CONCEIÇÃO, A.S. Malvoideae Burnett (Malvaceae) in the Environmental Protection Area Serra Branca, Raso da Catarina, Jeremoabo, Bahia, Brazil. Biota Neotropica. 16(4):e20160187. http://dx.doi. org/10.1590/1676-0611-BN-2016-0187

\begin{abstract}
Malvoideae is the largest subfamily of Malvaceae, including 110 genera and 1,730 species distributed predominantly in tropical regions, with a few representatives in temperate regions. In Brazil, the subfamily occurs throughout the country and all phytogeographic domains. The floristic survey of Malvoideae in the Environmental Protection Area Serra Branca included analysis of 43 specimens collected from August 2011 to February 2013. The analysis were supplemented with dried collections from the following herbaria: ALCB, HUEFS and MAC. Six genera and sixteen species were recorded. Sida L. was the most representative genus with five species [S. angustissima A.St.-Hil., S. castanocarpa Krapov., S. cordifolia L., S. galheirensis Ulbr., S. linifolia Cav. and S. spinosa L.], followed by Pavonia Cav. with three species [P. blanchetiana Miq., P. cancellata (L.) Cav. and P. glazioviana Gürke], Sidastrum Baker with three species [S. micranthum (A.St.-Hil.) Fryxell, S. multiflorum (Jacq.) Fryxell and S. paniculatum (L.) Fryxell] and Herissantia Medik. with two species [H. crispa (L.) Brizicky and H. tiubae (K.Schum .) Brizicky]. The remainging genera were represented by one species each: Pseudabutilon virgatum (Cav.) Fryxell and Malvastrum tomentosum (L.) S.R.Hill. The majority of the species recorded in the area have a Neotropical distribution, and six species are endemic to Brazil, among which the species Herissantia tiubae, Sida galheirensis, Pavonia blanchetiana and Pavonia glazioviana are endemic to the Northeast Region, the latter two species occurring exclusively in the Caatinga biome. The taxonomic treatment includes a key for the identification, descriptions, illustrations, photos, data of the geographical distribution, economic potential and reproductive phenology and comments about the species.
\end{abstract}

Keywords: biodiversity, morphology, taxonomy, Caatinga, semiarid.

\section{Malvoideae Burnett (Malvaceae) na Área de Proteção Ambiental Serra Branca, Raso da Catarina, Jeremoabo, Bahia, Brasil}

Resumo: Malvoideae é a maior subfamília de Malvaceae, incluindo 110 gêneros e 1.730 espécies, distribuídas nas regiões tropicais, com alguns representantes em regiões temperadas. No Brasil, a subfamília está representada em todo o território nacional e domínios fitogeográficos. O levantamento florístico das Malvoideae na Área de Proteção Ambiental Serra Branca compreendeu a análise de 43 espécimes coletados no período de agosto/2011 a fevereiro/2013. As analises foram complementadas com coleções herborizadas depositadas nos seguintes herbários ALCB, HUEFS e MAC. Foram catalogados seis gêneros e dezesseis espécies. Sida L. foi o gênero mais representativo com cinco espécies [S. angustissima A.St.-Hil., S. castanocarpa Krapov., S. cordifolia L., S. galheirensis Ulbr., S. linifolia Cav. e S. spinosa L.], seguido de Pavonia Cav. com três espécies [P. blanchetiana Miq., P. cancellata (L.) Cav. e P. glazioviana Gürke], Sidastrum Baker com três espécies [S. micranthum (A.St.-Hil.) Fryxell, S. multiflorum (Jacq.) Fryxell e S. paniculatum (L.) Fryxell] e Herissantia Medik. com duas espécies [H. crispa (L.) Brizicky e H. tiubae (K.Schum.) Brizicky]. Os demais gêneros estão representados por uma espécie cada um, Pseudabutilon virgatum (Cav.) Fryxell e Malvastrum tomentosum (L.) S.R.Hill. A maioria das espécies ocorrentes na área possui distribuição neotropical e seis espécies são endêmicas do Brasil, destas Herissantia tiubae, Sida galheirensis, Pavonia blanchetiana e Pavonia glazioviana são endêmicas da região Nordeste, as duas últimas espécies de ocorrência exclusiva no bioma caatinga. São apresentados comentários sobre morfologia e taxonomia, ilustrações, e dados sobre distribuição geográfica e fenologia, além de uma chave para os táxons estudados. O tratamento taxonômico inclui uma chave de identificação, descrições, ilustrações, fotos, dados de distribuição geográfica, potencial econômico, fenologia reprodutiva e comentários sobre as espécies.

Palavras-chave: biodiversidade, morfologia, taxonomia, Caatinga, semiárido. 


\section{Introduction}

Malvaceae $s . l$. includes nine subfamilies: Grewioideae Hochr., Tilioideae Arn., Brownlowioideae Burret, Bombacoideae Burnett, Malvoideae Burnett, Byttnerioideae Burnett, Helicterioideae (Schott \& Endl.) Meisn., Sterculioideae Burnett and Dombeyoideae Beilschm. (Bayer et al. 1999). The subfamily Malvoideae embraces all genera of Malvaceae s.s., and some genera traditionally placed in Bombacaceae and Sterculiaceae, showing as synapomorphy simple leaves (Baum et al. 2004). The subfamily is the largest within of Malvaceae s.l. including 110 genera and 1,730 species distributed in the tropics, especially in the New World, with a few representatives in temperate regions (Bayer \& Kubitzki 2003). In Brazil, Malvoideae is represented throughout the country and in all phytogeographical domains, with Pavonia Cav., Abutilon Mill., Sida L. and Hibiscus L. being the most represented genera (Bovini et al. 2016).

In Brazil, Malvoideae were treated in various lists or monographic studies of local floras and state, such as: Flórula of Mucugê, BA (Fryxell 1986), Flora of the Pico das Almas, BA (Fryxell 1995), Agreste Paraibano, PB (Alves et al. 2011), Flora de Mirandiba, PE (Amorim et al., 2009), Flora of the San Francisco River, CE, PB and PE (Siqueira Filho et al. 2012), Flora da Serra do Cipó, MG (Esteves, 1986), Flora de Grão-Mogol, MG (Esteves \& Krapovickas 2009), Parque Estadual do Rio Doce, MG (Bovini et al. 2001), Flora de São Paulo (Takeuchi \& Esteves 2012), Reserva do Rio das Pedras, RJ (Bovini 2010), Flora da Reserva Ducke, AM (Esteves 2006), Pavonia do Rio Grande do Sul (Grings 2011), Malvaceae Brasiliensis (Monteiro Filho 1955), Catálogo de Plantas e Fungos do Brasil (Bovini et al. 2010) and Lista da flora do Brasil (Bovini et al. 2016).
Economically, members of Malvoideae are important in the textile industry and as food, such as species of Gossypium L. and Abelmoschus Medik., respectively. Some species are used mainly as ornamentals, such as Hibiscus, Malvaviscus Fabr., Abutilon and Pavonia. The subfamily also includes several species of Abutilon, Sida, Urena L., Malvastrum A.Gray. and Herissantia Medik., that produce fibers used in the strings with medicinal potential and weeds species or ruderal (Takeuchi 2011, Souza \& Lorenzi 2012).

Given the importance of the subfamily Malvoideae, and the scarcity of information about the subfamily for the Caatinga biome, the present study aimed to survey species of Malvoideae (Malvaceae) occurring in the Environmental Protection Area Serra Branca (EPASB), in order to contribute to knowledge about the flora of the semiarid region of Bahia as well provide support for the development of plans to manage the conservation unit.

\section{Material and Methods}

The Evironmental Protection Area Serra Branca, Raso da Catarina (EPASB, Figure 1) comprises 67,237 ha, located in the municipality of Jeremoabo in Northeastern Bahia fully inserted into the "polígono das secas" (Fundação CTI/NE 2016), delimited by the coordinates $09^{\circ} 53$ ' $15.5^{\prime}$ " to $09^{\circ} 44^{\prime} 34.6$ "S and $38^{\circ} 49^{\prime} 36.1$ "to $38^{\circ} 52^{\prime} 20.4$ 'W, limited to the South with the Vaza-Barris River and North to the Ecological Station Raso da Catarina (ESEC). The predominant vegetation is the sandy, very dense bushy Caatinga. The climate of the Ecoregion is semiarid, with average rainfalls of $500 \mathrm{~mm} /$ year and annual temperature is approximately $23^{\circ} \mathrm{C}$ (Szabo et al. 2007). The soils are generally sandy deep and very fertile relief plan with sandstone formations (Velloso et al. 2002).

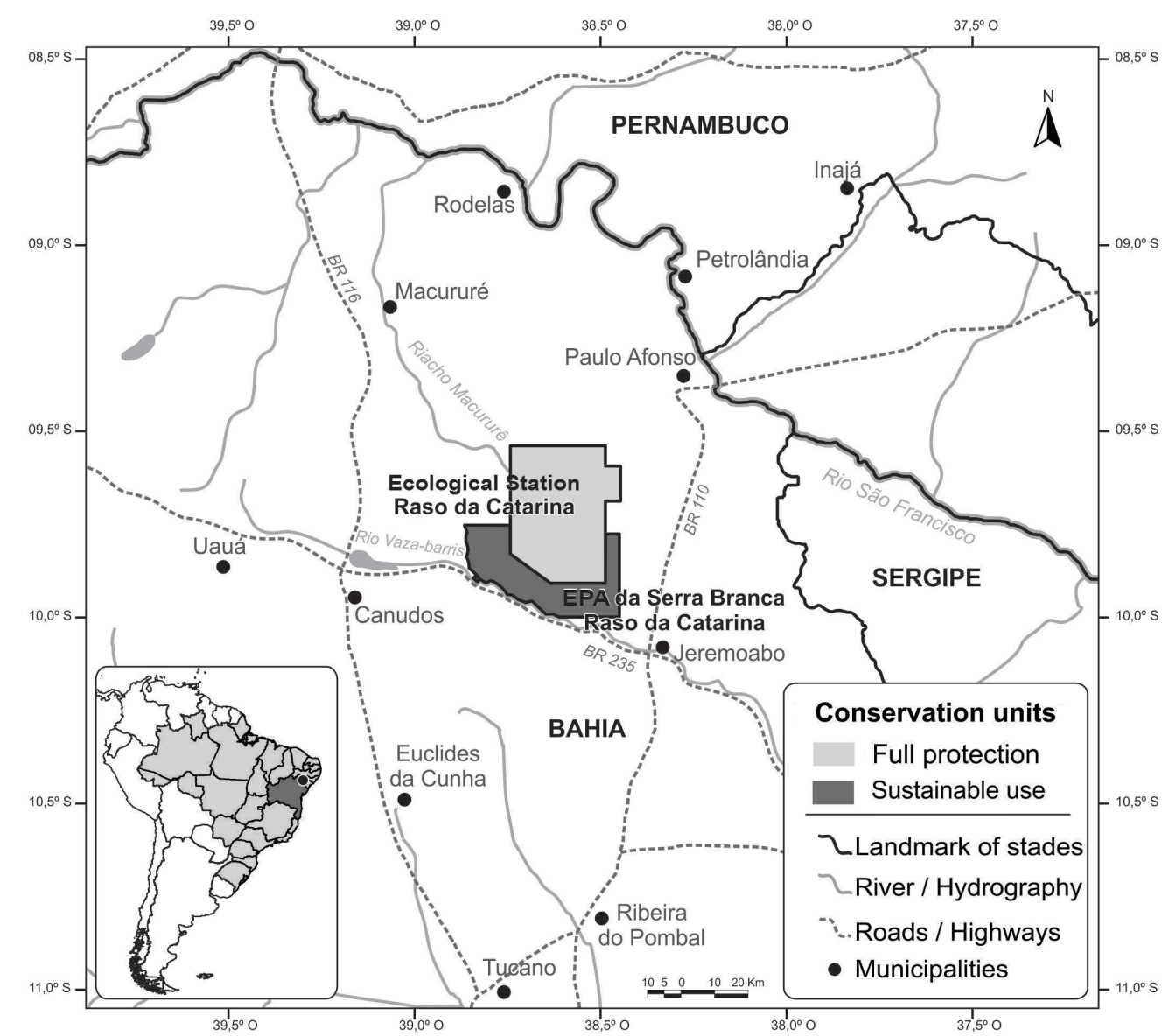

Figure 1. Location EPA Serra Branca, Raso da Catarina, Bahia, Brazil (Varjão et al. 2013). 
The study was based on fieldwork carried out in the period August/2011 to February/2013, besides information complemented by the analysis of specimens deposited in the following herbaria: ALCB, MAC and HUEFS, acronyms according to Thiers 2016 (continuously updated). The field collections and observations were performed during random walks exploring most of the study area. The herborization and material processing followed the methodology by Fosberg \& Sachet (1965) and Mori et al. (1989), where fertile material was collected with flowers and/or fruit. Observations were made about the distribution of the species and the type of soil (Tricart 1972, Sampaio 1995). The specimens were deposited in the herbarium of the State University of Bahia (HUNEB - Collection Paulo Afonso) and the duplicates will be sent to the main herbaria in the state of Bahia (ALCB, HRB and HUEFS).

The identifications were made based mainly on specialized bibliographies, protologues, photos of type collections and comparison of the collections in the herbaria that were visited. For the taxonomic descriptions, the terminologies proposed by Harris \& Harris (2001) and Gonçalves \& Lorenzi (2011) were adopted. The taxonomic treatment includes a key for the identification, descriptions, illustrations, photos, data of the geographical distribution, economic potential and reproductive phenology and comments about the species.

\section{Results and Discussion}

\section{Malvoideae Burnett}

Subshrubs or shrubs. Branches with simple, stellate or glandular trichomes. Leaves simple, alternate, petiolate, stipulate. Perfect flowers, showy, solitary and/or inflorescence terminal or axillary; with or without epicalyx; calyx with five sepals, gamosepalous, pentalobed, aestivation valvate; corolla with five petals, free each other, adnate at the base of the staminal tube, aestivation imbricate, differently colored, with or without a basal spot; numerous stamens, monadelphous, free parts of stamens concentrated in the apex of staminal tube or variously distributed along it, anthers monothecal, dorsifixed, rimoses, usually yellow; ovary superior, carpels 5-many, uni to pluriovulate, placentation axile, styles in equal or double the number of carpels, stigmas capitate. Fruits schizocarps, mericarps 5-many, rostrate, aristate or muticous; 1-many seeds, glabrous or hairy.

In the EPASB, Malvoideae are represented by sixteen species encompassing six genera: Herissantia Medik., Malvastrum A.Gray, Pavonia Cav., Pseudabutilon R.E.Fr., Sida L. and Sidastrum Baker. Sida, with six species, was the most representative genus, followed by Pavonia and Sidastrum, with three species each. Pavonia glazioviana Gürke and Sida galheirensis Ulbr. were the most collected species in subshrubby and shrubby-arborescent Caatinga environments associated with sandy soils predominant in the area. The least representative species, were Sida angustissima A.St.-Hil., Sida linifolia Cav., Sida spinosa L. and Sidastrum micranthum (A.St.-Hil.) Fryxell, collected only once.

The majority of species occurring in the EPASB have a Neotropical distribution. Sida angustissima, Sida castanocarpa Krapov., Herissantia tiubae (K.Schum.) Brizicky, Sida galheirensis, Pavonia blanchetiana and Pavonia glazioviana are endemic to Brazil, among these four species are endemic to the Northeast, latter two species occurring exclusively in the Caatinga biome (Fryxell 1973, Bovini 2016a, d, Esteves 2016).

Many species that occur in the EPASB are of economic importance, such as having potential value for beekeeping. Sida galheirensis, Sida cordifolia L. and Herissantia spp. are used as fodder, while Pavonia cancellata (L.) Cav., Sida cordifolia, Sida spinosa and Sidastrum micranthum (A.St.-Hil.) Fryxell all have potential medicinal value (Sampaio et al. 2005).

\section{Identification key for the representatives of the subfamily} Malvoideae

1. Epicalyx present.

2. Epicalyx with 3 bracteoles. Free portion of the stamens concentrated at the apex of the staminal tube. Styles in equal number of carpels. Mericarps 3-awned............................... 3. Malvastrum tomentosum 2'. Epicalyx with more than 3 bracteoles. Free portion of the stamens distributed along of the staminal tube. Styles in double the number of carpels. Mericarps muticous to rostrate.

3. Epicalyx with 20-22 bracteoles. Mericarps winged laterally. 4. Pavonia blanchetiana

3'. Epicalyx with 12-14 bracteoles. Mericarps not winged.

4. Bracteoles filiforms, green. Petals yellow with vinaceous basal spot....... 5. Pavonia cancellata 4'. Bracteoles linear-lanceolate, green at the basal portion, pink at the apical portion, sometimes entirely pink. Petals pink

6. Pavonia glazioviana

1 '. Epicalyx absent.

5. Schizocarp inflated.

6. Branches with trichomes stellate. Petals 5-8 mm long. Stamens c. 30. Mericarps 10, with trichomes simple......... 1. Herissantia crispa 6'. Branches with glandular trichomes predominantly, simple sparse trichomes. Petals 18-20 mm long. Stamens c. 50. Mericarps 12-17, with trichomes stellate. 2. Herissantia tiubae 5'. Schizocarp not inflated.

7. Schizocarp with three seeds per mericarp..

7'. Schizocarp with one seed per mericarp.

8. Calyx with prominent venation.

9. Leaf with blade linear to narrow elliptic. 10. Leaf with margin serrate. Petals yellow-orange with reddish base. Mericarps long biaristate ................

8. Sida angustissima

$10^{\prime}$. Leaf with margin entire. Petals white with vinaceous basal spot. Mericarps muticous ........... 12. Sida linifolia

9'. Leaf with blade ovate to elliptic.

11. Subshrubs not prostrate. Mericarps not muricate, biaristate, with white simple trichomes, only in the aristas. Seeds glabrous.

12. Petiole with a purple spine. Petals white with yellow basal spot. Mericarps 5 .

13. Sida spinosa

12'. Petiole without spine. Petals yellow-orange with reddish-vinaceous basal spot. Mericarps more than 5 .

13. Branches and leaves velutinous; blade with base cordate. Inflorescences glomeruliforms dense. Mericarps c. $5 \mathrm{~mm}$ long, biaristate, arista parallel between them............. 10. Sida cordifolia 13'. Branches hirsute and leaves pubescents; blade with base obtuse to subcordate. Flowers solitary. Mericarps c. $3 \mathrm{~mm}$ long, biaristate, arista divergent.

11. Sida galheirensis

11'. Subshrubs prostrate. Mericarps muricate, not aristate, with brown stellate trichomes, on the mericarp. Seeds pilose. 9. Sida castanocarpa

8'. Calyx without prominent venation.

14. Petals yellow, more than $5 \mathrm{~mm}$ long. Mericarps 10 .. 15. Sidastrum multiflorum

14 '. Petals vinaceous or yellow with pink basal spot, 4-5 mm long. Mericarps 5. 
15. Inflorescences glomeruliform; flowers subsessiles or pedicels $0.5-1.5 \mathrm{~mm}$ long; petals yellow with pink basal spot.

14. Sidastrum micranthum

15'. Inflorescences paniculate, flowers pedicellate $1.5-2 \mathrm{~cm}$ long; petals vinaceous.

\section{Sidastrum paniculatum}

1. Herissantia crispa (L.) Brizicky, J. Arnold Arbor. 49: 279. 1968 Iconografia: Schumann (1891: 70), Fryxell (1988: 191), Rondón (2009: 609). Figures 2a, 3a

Subshrubs decumbent c. $50 \mathrm{~cm}$ tall; branches tomentose, trichomes stellate. Stipules linear 6-9 mm long. Leaf with blade 2-6 $\times 2-5 \mathrm{~cm}$, ovate, discolorous, membranaceous, pubescent on both faces, trichomes stellate, apex acuminate, basis cordate, margin dentate; petioles 1-2.5 cm long, tomentose. Flowers solitary, axillary or terminal; pedicels 1-2.5 cm long; epicalyx absent; calyx 4-6 mm long; cupuliform, not prominent venation, externally with simple and stellate trichomes, internally with simple trichomes only at the apex, lobes acute-acuminate; petals 5-8 $\times 3-6 \mathrm{~mm}$, obovate, white with yellow basal spot, glabrous; stamens c. 30 , staminal tube 2-3 mm long, free portion of the stamens 3-4 mm long, concentrated at the apex of the tube; ovary c. $1 \times 1.5 \mathrm{~mm}$, subglobose, glabrous; carpels 10, uniovulate; styles 10, 3-5 mm long. Schizocarp subglobose, inflated, pendulum, mericarps 10 , c. $1.5 \times 1.5 \mathrm{~cm}$, trichomes simple, white, lateral face fragile; seeds 1 per mericarps, c. $2.1 \times 2 \mathrm{~mm}$, reniform, nigrescent, sparsely hairy.

Material examined: APA Serra Branca, Caminho sentido Serra no Navio, 951'58.1'S 38³8'46.9'W, 482 m, 03.XI.2011, fl., J.B. Lima 09 (HUNEB); Estrada do Tamburi, próximo a baixa dos Quelés, 957'43.0"S 38²5'33.3”W, 514 m, 09.VII.2012, fl.; fr., J.B. Lima 24 (HUNEB).

A species with a Pantropical distribution (Fryxell 1997). In Brazil it occurs only in the Northeast Region (Alagoas, Bahia Pernambuco and Sergipe), in areas of Caatinga and Cerrado environments (Bovini 2016a).
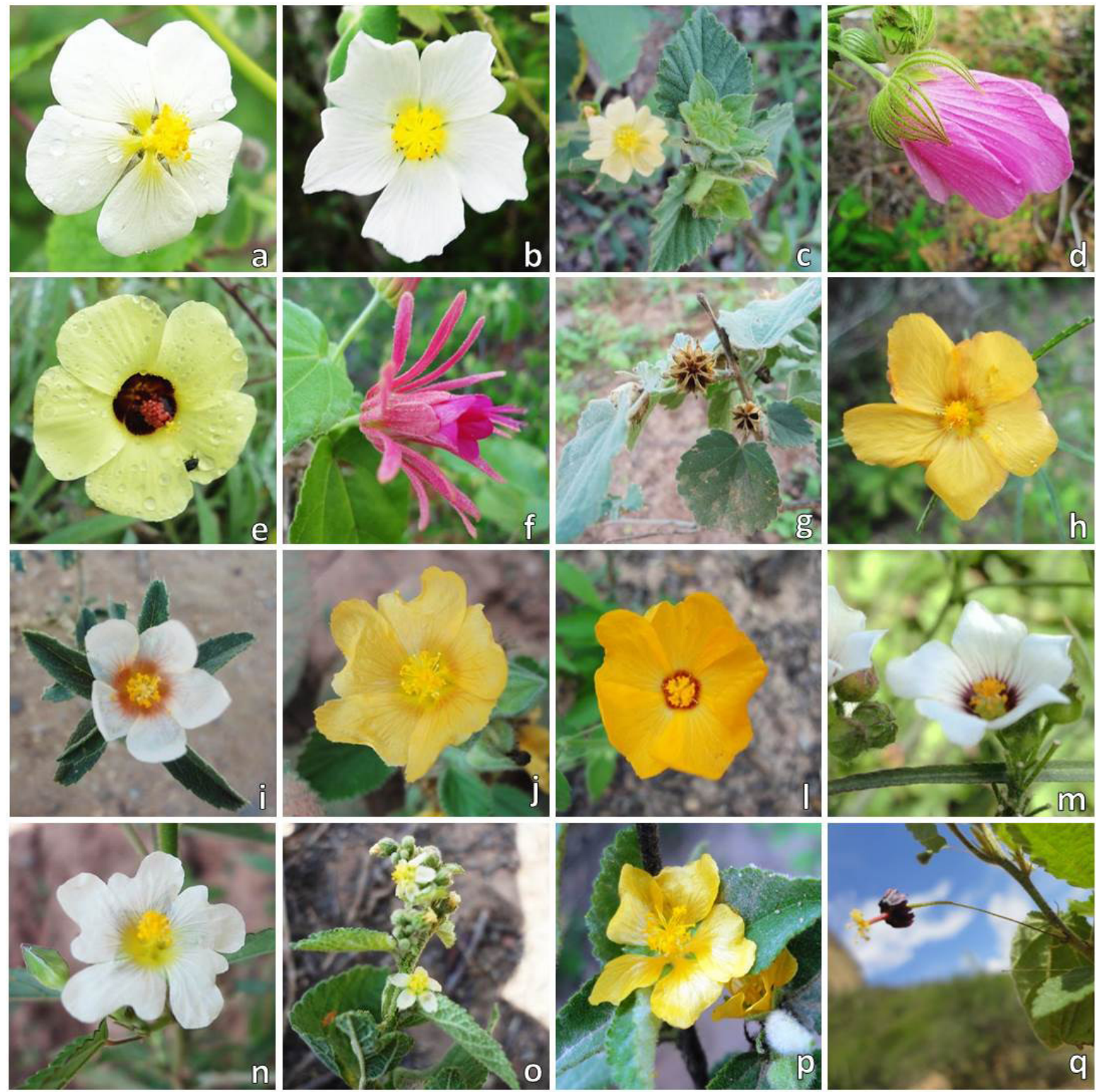

Figure 2. Representatives of the Malvoideae in the EPASB. a. Herissantia crispa; b. Herissantia tiubae; c. Malvastrum tomentosum subsp. tomentosum; d. Pavonia blanchetiana; e. Pavonia cancellata; f. Pavonia glazioviana; g. Pseudabutilon virgatum; h. Sida angustissima; i. Sida castanocarpa; j. Sida cordifolia; 1 . Sida galheirensis; m. Sida linifolia; n. Sida spinosa; o. Sidastrum micranthum; p. Sidastrum multiflorum; q. Sidastrum paniculatum. 
The species shares with $H$. tiubae morphological characters as white corolla with a yellow base and an inflated schizocarp and pendulum. However, $H$. crispa can easily be differentiated by its decumbent habit, indument consisting predominantly of stellate trichomes, always having smaller leaves and flowers and mericarps with simple trichomes ( $v s$. mericarps with stellate trichomes). In EPASB, H. crispa was found along edges of trails and on mountain slopes in Caatinga on sandy soils. Specimens were collected with flowers and fruits virtually all year round. The species has beekeeping and forage potential (Sampaio et al. 2005).

2. Herissantia tiubae (K.Schum.) Brizicky, J. Arnold Arbor. 49: 279. 1968. Figures 2b, 3i, 4a-e

Subshrush 0.5-1.2 m tall; branches tomentose, glandular trichomes predominantly, simple sparse trichomes. Stipules linear 2-3 mm long. Leaf with blade 2.5-8 (-14) $\times 1.5-5(-9) \mathrm{cm}$, ovate, discolorous, membranaceous, adaxial face pubescent, abaxial face tomentose, trichomes stellate, apex acuminate, basis cordate, margin serrate; petioles 1-8 cm long, tomentose. Flowers solitary, axillary or terminal; pedicels $1.5-2.5 \mathrm{~cm}$ long; epicalyx absent; calyx 6-8 mm long, cupuliform, not prominent venation, externally with stellate trichomes, internally simple trichomes only at the apex, lobes acuminate; petals $18-20 \times 13-15 \mathrm{~mm}$, obovate, white with yellow basal spot, glabrous; stamens c. 50, staminal tube 3-3.5 mm long, free portion of the stamens 3-4 mm long, concentrated at the apex of the tube; ovary c. $1.5 \times 2 \mathrm{~mm}$, subglobose, glabrous; carpels 12-17, uniovulate, styles 12-17, 5-7 mm long. Schizocarp subglobose, inflated, pendulum; mericarps $12-17,1.6-2 \times$ c. $1.8 \mathrm{~cm}$, trichomes stellate, white, lateral face fragile; seeds 1 per mericarp, c. $1.8 \times 2 \mathrm{~mm}$, reniform, nigrescent, sparsely hairy.
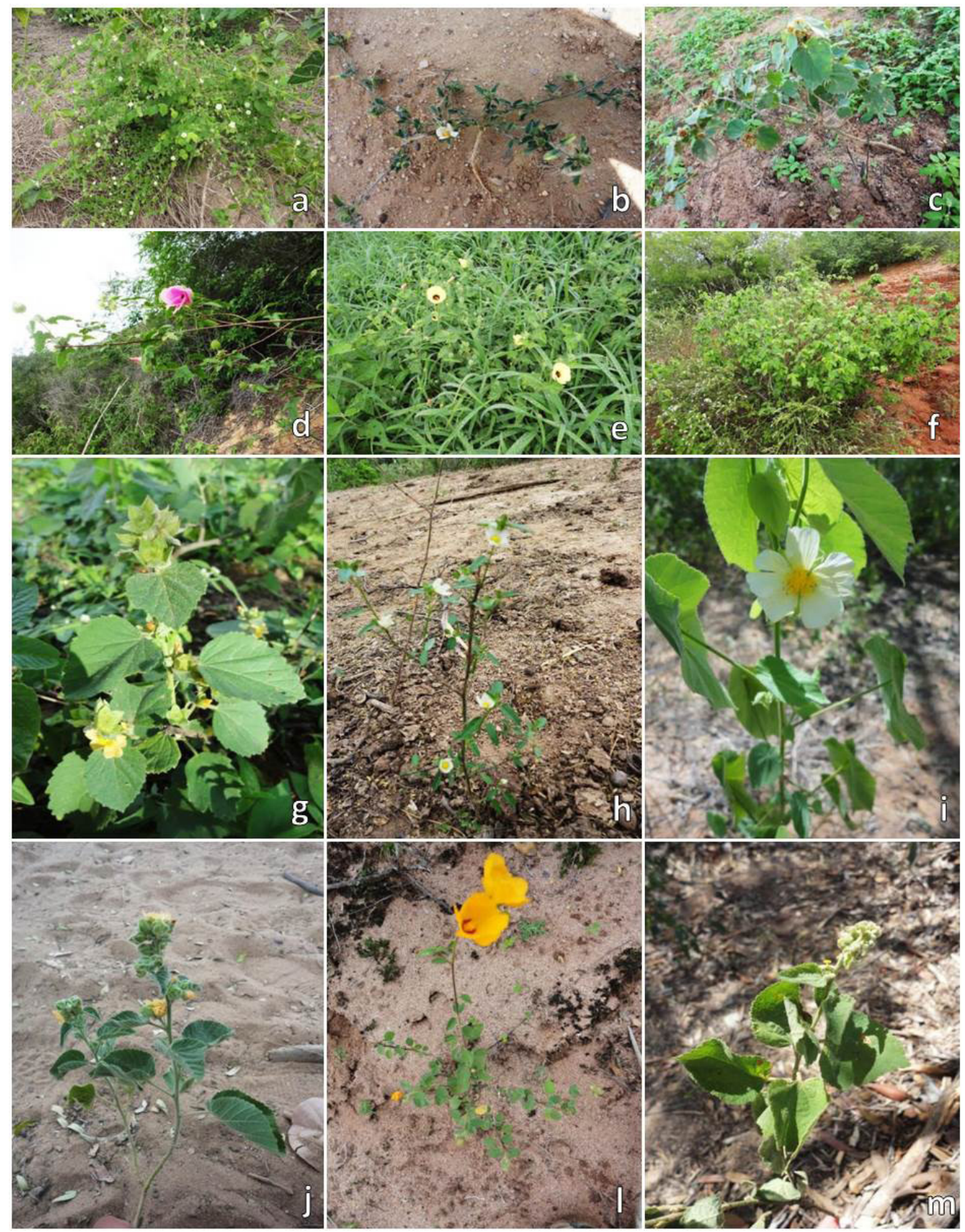

Figure 3. Habits of the Malvoideae in the EPASB. a. Herissantia crispa; b. Sida castanocarpa; c. Pseudabutilon virgatum; d. Pavonia blanchetiana; e. Pavonia cancellata; f. Pavonia glazioviana; g. Malvastrum tomentosum subsp. tomentosum; h. Sida spinosa; i. Herissantia tiubae; j. Sida cordifolia; 1 . Sida galheirensis; m. Sidastrum micranthum. 
Material examined: APA Serra Branca, Caminho da Judite próximo a Serra do Navio, 951'55.5”S 38³8'45”W, 469 m, 03.XI.2011, fl., J.B. Lima 05 (HUNEB); Base da vaca morta, 955'17,2"S 38 42'06”W, 392 m, 10.VII.2012, fl.; fr., J.B. Lima 33 (HUNEB); Trilha sentido Saco do Cedro, 952'05.1'S 38³8'12.8”W, 489 m, 30.VII.2009, fl., A.S. Conceição 1848 (HUNEB); Fazenda Serra Branca, trilha sentido Serra do Navio, 9'52'49.1'S 38॰39’22,0”'W, 481 m, 31.VII.2009, fl.; fr., A.S. Conceição 1882 (HUNEB).

A species endemic to the Northeast Region of Brazil, it is found in Caatinga and Cerrado environments of all states of that region (Bovini 2016a).

In the study area it can be recognized mainly by its indument consisting predominantly of glandular trichomes, size of the leaves $(2.5-8 \mathrm{~cm}$ to $14 \mathrm{~cm})$ and mericarps (ca. $1.8 \times 2 \mathrm{~mm}$ ) higher than in other congeners species. In the study area, $H$. tiubae is associated with shrubby and shrubby-arborescent Caatinga on sandy soils. Specimens were collected with flowers and fruits virtually all year round. The species has beekeeping and forage potential (Sampaio et al. 2005).

3. Malvastrum tomentosum (L.) S.R.Hill subsp. tomentosum, Brittonia 32: 466. 1980. Figures 2c, 3g, 4f-h

Subshrubs $25-30 \mathrm{~cm}$ tall; branches pubescent, trichomes stellate. Stipules linear 2-3 mm long. Leaf with blade 1.5-4.5 × 1.5-4 cm, ovate, discolorous, membranaceous, tomentose on both faces, trichomes stellate, apex acuminate, basis truncated to obtuse, margin serrate; petioles $5-10 \mathrm{~mm}$ long, pubescent. Inflorescences cymes, axillary. Flowers with pedicel 1-2 mm

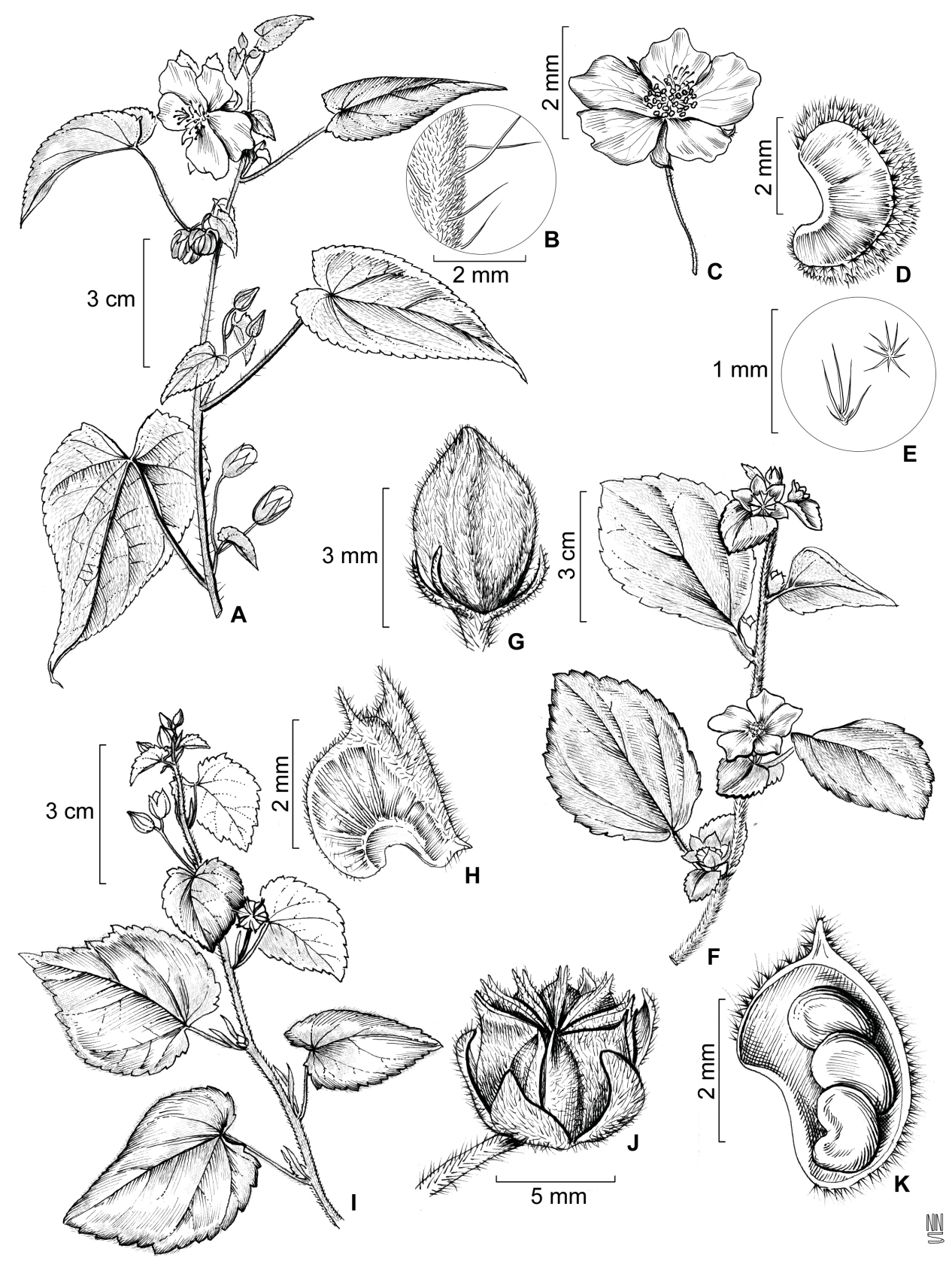

Figure 4. A-E. Herissantia tiubae. A. flowering branch; B. detail of branch indumentum; C. Flower; D. mericarp; E. detail of mericarp indumentum. F-H. Malvastrum tomentosum subsp. tomentosum; F. flowering branch; G. bud with epicalyx; H. mericarp; I-K. Pseudabutilon virgatum; I. branch; J. fruit; K. mericarp with three seeds. A-E from A.S. Conceição 1882; F-H from J.B. Lima 39; I-K from J.B. Lima 88. 
long; bracteoles of epicalyx 3, 4-5 mm long, linear, trichomes simple, green, pubescent; calyx 7-8 mm long, cupuliform, not prominent venation, lobes acute at the apex, externally with stellate trichomes, internally simple trichomes only at the apex; petals 5-7 $\times 4-5 \mathrm{~mm}$, obovate, entirely yellow, glabrous; stamens c. 35 , staminal tube $2-2.5 \mathrm{~mm}$ long, free portion of the stamens $0.5-1 \mathrm{~mm}$ long, concentrated at the apex of the tube; ovary c. $1 \times 2 \mathrm{~mm}$, discoid, glabrous, carpels $10-12$, uniovulate, styles $10-12,3-4 \mathrm{~mm}$ long. Schizocarp not inflated, mericarps 10-12, 2-2.5 × 2-4 cm, laterally compressed wedge-shaped, simple trichomes white, 3-awned, one central and two larger lateral awns; seeds 1 per mericarp c. $1.8 \times 1.5 \mathrm{~mm}$, reniform, nigrescent, slightly hairy.

Material examined: APA Serra Branca, Próximo a Serra do Navio, 9॰52'43.3”S 38³9'12.1’W, 473 m, 10.VII.2012, fl.; fr., J.B. Lima 38 (HUNEB); 10.VII.2012, fl.; fr., J.B. Lima 39 (HUNEB).

This taxon occurs in Peru, Ecuador, Venezuela and Brazil (Hill 1980), in the latter of which it occurs in the northeast (Bahia, Ceará, Paraíba, Pernambuco), midwest (Mato Grosso) and southeast (Minas Gerais), in Caatinga, Cerrado and Atlantic Forest environments (Bovini 2016b).

In EPASB, this species is easily recognized by having a epicalyx with 3 bracteoles, linear, mericarps laterally compressed wedge-shaped, 3-awned, one central and two larger side awn. It was collected with flowers and fruits in July in shrubby-arborescent Caatinga.

4. Pavonia blanchetiana Miq., Linnaea 22: 801. 1849. Iconografia: Gürke (1892: 101), Esteves (1998: 224), Fryxell (1999: 39). Figures 2d, 3d

Subshrubs 1.20-1.30 m tall; branches pubescent, trichomes stellate, trichomes simple forming 1-2 dense longitudinal lines. Stipules linear 3-4 mm long, pubescent. Leaf with blade 2-3 $\times 1.3-3.5 \mathrm{~cm}$, entire to trilobed, central lobe larger than lateral lobes, discolorous, chartaceous, apex acute, basis cordate to hastate, margin serrate, 3-5-nerved from the base, pubescent on both faces, trichomes stellate and simple; petiole $1.5-5 \mathrm{~cm}$ long, pubescent. Flowers solitary, axillary; pedicels 1-2.5 cm long; bracteoles of epicalyx 20-22, 2.4-2.8 cm long, linear, green, long ciliate; calyx 0.8-1.2 cm long, campanulate, not prominent venation, externally with simple trichomes, internally trichomes only at the apex, lobes acute at the apex; petals $3.5-5 \times 2.5-4 \mathrm{~cm}$, obovate, pink with vinaceous basal spot, externally with stellate trichomes; stamens c. 40 , staminal tube 1.3-1.5 mm long, free portion of the stamens $1-1.5 \mathrm{~mm}$ long, distributed $2 / 3$ at apex of the tube and some concentrated at the base of the tube, anthers purple; ovary c. $2 \times 3 \mathrm{~mm}$, ellipsoid, trichomes glandular, carpels 5, uniovulate, styles $10,1-1.3 \mathrm{~cm}$ long. Schizocarp not inflated; mericarps 5 , c. $1.1 \times 0.7 \mathrm{~cm}$, rostrate at the apex, winged laterally, trichomes stellate, ferruginous; seeds 1 per mericarp, c. $4.5 \times 2 \mathrm{~mm}$, reniform, nigrescent, glabrous.

Material examined: APA Serra Branca, Estrada do Tamburi, próximo a baixa dos Quelés, 957'43”'S 38²5'33.3”W, 514 m, 09.VII.2012, fl.; fr., J.B. Lima 21 (HUNEB); Baixa Grande, sentido Areia Branca, 958'43.1's 38²7'14.0”W, 561 m, 19.III.2009, fl., A.S. Conceição 1573 (HUNEB).

This species is endemic to the Northeast Region of Brazil and is found in the states of Alagoas, Bahia, Pernambuco and Sergipe, occurring exclusively in Caatinga environments (Esteves 1998, Esteves 2016).

Pavonia blanchetiana can be easily distinguished from other species occurring in EPASB by its pink petals with a vinaceous base, epicalyx with 20-22 bracteoles, linear, green, long ciliate and mericarps winged laterally. The species was collected with flowers and fruits in July and March on sandy soils, near mountain slopes.

5. Pavonia cancellata (L.) Cav., Diss. 3: 135. 1787. Iconografia: Gürke (1892: 98), Esteves (1998: 225), Rondón (2009: 610), Esteves \& Krapovickas (2009: 69), Esteves (2001: 166). Figures 2e; 3e

Subshrubs prostrate; ascending branches when flowering, hirsute, trichomes simple. Stipules linear 3-5 mm long. Leaf with blade 1.5-4 × 1-4 cm, ovate to triangulate, discolorous, chartaceous, apex acute, basis subcordate, cordate to hastate in general asymmetric, margin irregularly serrate, 5-7-nerved from the base, pilose on both faces, trichomes simple, adpressed; petioles 1-2.5 cm long, hirsute. Flowers solitary, axillary; pedicels 3-6 cm long; bracteoles of epicalyx 12-14, 1.2-1.4 cm long, filiform, green, ciliate; calyx 6-8 mm long, cupuliforme, not prominent venation, externally with simple trichomes, internally trichomes only at the apex, lobes acute at the apex; petals $2.5-3 \times 2-2.5 \mathrm{~cm}$, obovate, yellow with vinaceous basal spot, glabrous; stamens c. 38 , staminal tube 1.5-2.1 mm long, free portion of the stamens 1-2 mm long, distributed along of the tube, anthers vinaceous; ovary c. $1.2 \times 2 \mathrm{~mm}$, subglobose, glabrous, carpels 5 , uniovulate, styles 10, 2-2.2 cm long. Schizocarp not inflated; mericarps c. $5.5 \times 3 \mathrm{~cm}$, muticous to shortly rostrate, glabrous, lateral face resistant; seeds 1 per mericarp c. $3 \times 2 \mathrm{~mm}$, reniform, orange, simple trichomes.

Material examined: APA Serra Branca, Estrada do Tamburi, próximo a baixa dos Quelés, 9०57'43”'S 38²5'33.3”'W, 514 m, 09.VII.2012, fl.; fr., J.B. Lima 22 (HUNEB); 957'41.9”S 38²5’32.3”W, 509 m, 03.IX.2012, fl.; fr., J.B. Lima 47 (HUNEB); Caminho da ESEC em direção ao povoado Quelés, 953'01'S 38³2’39”W, 650 m, 22.IX.2010, fl., D.D. Vieira 98 (HUNEB); Estrada saindo dos Quelés sentido ESEC Raso da Catarina, 9॰58'00.8”'S 38²6'11.7’'W, 497 m, 29.VII.2009, fl., A.S. Conceição 1798 (HUNEB).

A species with a Neotropical distribution occurring from North America (Mexico) to South America (Esteves 1998). In Brazil it occurs in almost all regions and phytogeographical domains. In the Northeast Region it was found in the states of Alagoas, Bahia, Ceará, Maranhão, Paraíba, Pernambuco, Piauí and Sergipe (Esteves 2016).

Pavonia cancellata show a large polymorphism in the leaves, especially in the form and dimensions of the blades. It can be easily recognized when flowering by its ascending branches and yellow petals with a vinaceous basal spot. It was found in EPASB with flowers and fruits in July and September in open areas on sandy soils. The species has beekeeping and medical potential (Sampaio et al. 2005).

6. Pavonia glazioviana Gürke, F1. Bras. (Martius) 12(3): 524. 1892. Iconografia: Esteves (1998: 221). Figures 2f; $3 f$

Subshrubs 2-2.5 m tall; branches pubescent, trichomes stellate, dense at the apical portion. Stipules linear 3-4 mm long. Leaf with blade $3-10 \times 3-8 \mathrm{~cm}$, ovate, discolorous, chartaceous, apex acute, basis cordate, margin serrate, 5-7-nerved from the base, pubescent on both faces, trichomes stellate; petioles 5-4 cm long, pubescent. Flowers solitary, axillary; pedicels 2.5-4.5 cm long; bracteoles of epicalyx 12-14, 1.5-3.0 cm long, linear-lanceolate, green at the basal portion, pink at the apical portion, sometimes entirely pink, pubescent, ciliate; calyx 1-2 cm long, tubiform, not prominent venation, greenish at the basal portion, pink at the apical portion, externally pubescent, trichomes stellate, internally glabrous, lobes rounded at the apex; petals c. $2.0 \times 0.8 \mathrm{~mm}$, obovate, pink, trichomes stellate externally; stamens c. 50, staminal tube 1.3-2.5 mm long, free portion of the stamens 2-4 mm long, distributed along of the tube, anthers purple; ovary 2.5-3 $\times$ 4-5 mm, globose to ovoid, glabrous, carpels 5, uniovulate, styles $10,2-2.3 \mathrm{~cm}$ long. Schizocarp not inflated; mericarps 5 , c. $1.3 \times 0.3 \mathrm{~cm}$, shortly rostrate, trichomes stellate white, lateral face resistant; seeds 1 per mericarp c. $3 \times 1.5 \mathrm{~mm}$, reniform, brown, trichomes stellate.

Material examined: APA Serra Branca, Estrada próxima a roça velha, 953'03.6”'S 38³9'46.8'W, 380 m, 04.XI.2011, fl., J.B. Lima 12 (HUNEB); Trilha para a vaca morta, 955'15.7'S 3842'04.3”'W, 365 m, 04.XI.2011, fl., J.B. Lima 17 (HUNEB); Estrada que vai da ESEC Raso da Catarina em direção ao povoado Quelés, 9०53'01'S 38³2'39"W, 650 m, 22.IX.2010, fl., D.D. Vieira 94 (HUNEB); Trilha da vaca morta. 9॰55'17’'S 3842'06”W, 392 m, 20.XII.2011, fl.; fr., J.V. dos Santos 01 (HUNEB); Fazenda Serra Branca, há 9,5 Km da distância da Base, trilha do Araçá, 952'49”'S 38³8'14”'W, 535 m, 08.V.2008, fl.; fr., M.V. Romão 130 (HUNEB); Fazenda Serra Branca, c. 2 km da base da Vaca Morta, 953'15”S 3840'08”W, 424 m, 17.IV.2008, bot.; fl., A.S. Conceição 1309 
(HUNEB); Trilha do tanque das pedrinhas, 9॰53'27.9''S 38॰40’48”'W, 474 m, 26.VI.2008, fl., A.S. Conceição 1403 (HUNEB).

An endemic species of the Northeastern Region of Brazil, occurring in the states of Piauí, Ceará and Pernambuco to Bahia and found exclusively in Caatinga environments (Esteves 1998, Esteves 2016).

Pavonia glazioviana can be clearly distinguished from other species by epicalyx with 12-14 bracteoles, linear-lanceolate, green in the basal portion, pink in the apical portion, sometimes entirely pink and pink corolla. It exhibits wide variation in the dimensions of the leaves, and is abundant in EPASB being found in both dry as wet periods in areas of shrubby-arborescent Caatinga and in a transition zone between Caatinga and semideciduous forest on sandy soils.

7. Pseudabutilon virgatum (Cav.) Fryxell. Contr. Univ. Michigan Herb. 21: 191. 1997. Figures 2g; 3c; 4i-k

Subshrubs $25-30 \mathrm{~cm}$ tall; branches pubescent, trichomes stellate and glandular. Stipules linear 6-10 mm long, trichomes stellate. Leaf with blades 2.3-6 $\times 1.5-4.9 \mathrm{~cm}$, ovate, discolorous, chartaceous, apex acuminate to acute, basis cordate, margin sparsely serrate, pubescent on both sides, stellate trichomes; petioles 1-2.8 cm long, tomentoses. Inflorescences fasciculate or flowers solitary, axillary; pedicels $0.8-1.2 \mathrm{~cm}$ long; epicalyx absent; calyx 7-8 mm long, campanulate, venation prominent, externally with stellate trichomes, internally with simple trichomes only at the apex, lobes acute at the apex; petals $0.6-0.7 \times 0.5 \mathrm{~cm}$, obovate, yellow, glabrous; stamens c. 38 , staminal tube c. $2 \mathrm{~mm}$ long, free portion of the stamens c. $1 \mathrm{~mm}$ long, concentrated at the apex of the tube; ovary c. $2 \times 2 \mathrm{~mm}$, subglobose, glabrous, carpels 6-8, 3 ovules per locule, styles 6-8, c. $3 \mathrm{~mm}$ long. Schizocarp subglobose, not inflated; mericarps 6-8, 6-7 × 3-4 cm, shortly biaristate, arista with trichomes stellate white, fragile sides; seeds 3 per mericarp, $2 \times 2 \mathrm{~mm}$, reniform, dark brown, pilose.

Material examined: APA Serra Branca, Próximo a Serra do Navio, 9॰52'43.3”S 38³9'12.1”W, 473 m, 10.VII.2012, bot.; fr., J.B. Lima 40 (HUNEB); 9³1'54"S 38 38'44"W, 463 m, 09.V.2013, fr., J.B. Lima et al. 88 (HUNEB); 9³1'54"S 38॰38'44"W, 463m, 06.VI.2014, fl.; fr., J.B. Lima et al. 416 (HUNEB); Baixa do Tamburi, perto do Enterolobium, 957'46.3”S 38²6'12.7”W, 473 m, 26.III.2013, fr., J.V. dos Santos 64 (HUNEB).

This species occurs in Ecuador, Peru, Bolivia, Paraguay, Argentina and Brazil, in the latter of which it is spread throughout the northeast (Bahia and Pernambuco), midwest (Mato Grosso do Sul) and south (Paraná), occurring in Caatinga and Pantanal (Fryxel 1997, Bovini 2016c).

Pseudabutilon virgatum can be easily distinguished from other species occurring in EPASB by having an ovate leaf with a sparsely serrate margin and fruits with 3 seeds per mericarp. In the study area the species was collected on sandysoils with flowers and fruits virtually all year round.

8. Sida angustissima A.St.-Hil., F1. Bras. Merid. 1: 179. 1827. Iconografia: Brandão (2014: 101). Figures 2h; 5a-c

Subshrubs 50-70 cm tall; branches pubescent to glabrescent, trichomes stellate. Stipules linear 3-5 mm long, trichomes stellate. Leaf with blade $1.8-3.5 \times 0.2-0.3 \mathrm{~cm}$, linear to narrow elliptic, slightly discolores, chartaceous, apex acute, basis acute, margin serrate, uninerve, pubescent on both faces, trichomes stellate; petioles 3-5 mm long, pubescent, not spine. Flowers solitary, axillary or terminal; pedicels $0.5-1 \mathrm{~cm}$ long; epicalyx absent; calyx 4-7 mm long, cupuliform, venation prominent, externally with stellate trichomes, internally with trichomes only at the apex, lobes acute-acuminate at the apex; petals c. $1.2 \times 1 \mathrm{~cm}$, obovate, yellow-orange with reddish basal spot, glabrous; stamens c. 40, staminal tube 2-3 mm long, free portion of the stamens $0.8-1 \mathrm{~mm}$ long, concentrated at the apex of the tube; ovary c. $1 \times 1 \mathrm{~mm}$, subglobose, glabrous, carpels 7, uniovulate, styles 7, 5-6 mm long. Schizocarp not inflated; mericarps 7, 7-8 × c. $2 \mathrm{~mm}$, long biaristate, ariste parallel between them, with simple trichomes retrorse, white, lateral face reticulate, resistant; seeds 1 per mericarp c. $2 \times 1.5 \mathrm{~mm}$, reniform, nigrescent, glabrous.
Material examined: APA Serra Branca, Baixa grande após o povoado Quelés, roça de Mané de Chico, 958'30.7'S 38²6’20”W, 504 m, 03.IX.2012, bot.; fl.; fr., J.B. Lima 57 (HUNEB).

A species endemic to Brazil, occurring only in the southeast (Minas Gerais), midwest (Federal District) and northeast (Piauí, Ceará, Rio Grande do Norte, Paraiba, Pernambuco, Sergipe and Bahia), in Caatinga, Cerrado and Atlantic Forest environments (Bovini 2016d).

In the study area, Sida angustissima can be confused with S. linifolia Cav. because both have linear to narrow-elliptic leaves. However, S. angustissima can be distinguished from S. linifolia by having uninerve leaf blades with serrate margin ( $v s$. trinerve leaf blades with entire margin) and yellow-orange petals with a reddish base ( $v s$. white petals with a vinaceous basal spot). Esteves \& Krapovickas (2009) differentiate these species by mericarps long aristate in S. angustissima and muticous mericarps in S. linifolia. The species has beekeeping potential (Sampaio et al. 2005) and was collected only once during the rainy season.

9. Sida castanocarpa Krapov., Bonplandia 16(3-4): 226. 2007. Iconografia: Krapovickas (2007: 227). Figures 2i; 3b

Subshrubs prostrate; branches pubescent, trichomes stellate. Stipules linear to lanceolate 5-9 $\mathrm{mm}$ long, ciliate, trichomes stellate on the abaxial faces. Leaf with blade $0.6-1.7 \times 0.5-0.8 \mathrm{~cm}$, ovate to elliptic, discolorous, chartaceous, apex acute, basis obtuse, margin serrate at the portion apical, pubescent on both faces, trichomes stellate adpressed denser on abaxial face; petioles 3-6 mm long, pubescent, not spine. Inflorescences cymes terminal. Flowers pedicels 1-2 mm long; epicalyx absent; calyx 4-5 mm long, cupuliform, venation prominent, externally with simple trichomes, internally trichomes only at the apex, lobes acute-acuminate at the apex; petals c. $1 \times 0.4 \mathrm{~cm}$, obovate, white to salmon with red base, trichomes glandular on the dorsal face; stamens c. 16, staminal tube 1.8-2 mm long, free portion of the stamens c. $15 \mathrm{~mm}$ long, concentrated at the apex of the tube; ovary c. $1 \times 1.2 \mathrm{~mm}$, subglobose, simple trichomes, carpels 7 , uniovulate, styles 7, 4-5 mm long. Schizocarp not inflated; mericarps 7, c. $3 \times 2 \mathrm{~mm}$, muricate with brown stellate trichomes, lateral face reticulate, resistant; seeds 1 per mericarp c. $2 \times 2 \mathrm{~mm}$, reniform, brown, pilose.

Material examined: APA Serra Branca, Estrada do Tamburi, próximo a baixa dos Quelés, 9`57'43"'S 38²5'33.3”W, 514 m, 09.VII.2012, bot.; fl.; fr., J.B. Lima 25 (HUNEB); Povoado Quelés, 958'49.5”S 38²6’15”W, 516 m, 26.III.2013, bot.; fl.; fr., J.B. Lima 74 (HUNEB); 26.III.2013, bot.; fl.; fr., J.V. dos Santos 66 (HUNEB).

This species is endemic to Brazil, found in the midwest (Goiás) and northeast (Maranhão, Piauí, Ceará, Rio Grande do Norte and Bahia), in Caatinga and Cerrado environments (Bovini 2016d, Krapovickas 2007).

Sida castanocarpa in the study area is the only species of the genus that has a prostrate habit. Furthermore, it can be differentiated by white to salmon-colored petals and muricate mericarps with brown stellate trichomes. It was collected with flowers and fruits in March and July, in anthropized areas on sandy soils.

10. Sida cordifolia L., Sp. Pl. 2: 684. 1753. Iconografia: Rondón (2009: 613), Esteves \& Krapovickas (2009: 66), Brandão (2014: 105). Figures 2j; 3j

Subshrubs 50-60 cm tall; velutinous branches, trichomes stellate. Stipules linear 4-6 mm long, trichomes stellate. Leaf with blade $2.5-5.5 \times$ c. $2-5 \mathrm{~cm}$, ovate, slightly discolorous, membranaceous, apex obtuse to acute, base cordate, margin crenata, velutinous on both faces, trichomes stellate more dense on the abaxial face; petioles 3-6 mm long, velutinous, not spine. Inflorescences glomeruliforms dense, axillary and terminal. Flowers pedicels 3-6 mm long; epicalyx absent; calyx 6-8 mm long, cupuliform, venation prominent, externally with stellate trichomes, internally simple trichomes only at the apex, lobes acute-cuspidate at the apex; petals c. $1 \times 0.8 \mathrm{~cm}$, obovate, yellow-orange with pink base, externally with simple trichomes at the apex; stamens c. 60 , staminal tube $2-3 \mathrm{~mm}$ long, free portion of the stamens c. $15 \mathrm{~mm}$ long, concentrated at the apex of the tube; 
ovary 1-2 $\times$ c. $2 \mathrm{~mm}$, subglobose, glabrous, carpels 10 , uniovulate, styles $10,5-8 \mathrm{~mm}$ long. Schizocarp not inflated; mericarps 10 , c. $5 \times 2 \mathrm{~mm}$, long biaristate, arista parallel between them, with simple trichomes retrorse, white, lateral face reticulate, resistant; seeds 1 per mericarp c. $2 \times 1.5 \mathrm{~mm}$, reniform, nigrescent, glabrous.

Material examined: APA Serra Branca, Estrada para o povoado Quelés, ao lado do Enterolobium, 957'46.3”'S 38²6'12.7’'W, 478 m, 26.III.2013, bot.; fl.; fr., J.B. Lima 71 (HUNEB); Povoado Quelés, 958'49.5”S $38^{\circ} 26^{\prime} 15^{\prime \prime W}, 516$ m, 26.III.2013, bot.; fl.; fr., J.B. Lima 73 (HUNEB).

A species with a Pantropical and Subtropical distribution (Fryxell 1988). It is found in all regions of Brazil, occurring in Caatinga, Cerrado, Amazon Rainforest and Atlantic Forest environments. In the northeast the species was recorded in the states of Alagoas, Bahia, Ceará, Maranhão, Paraíba, Pernambuco and Sergipe (Bovini 2016d).

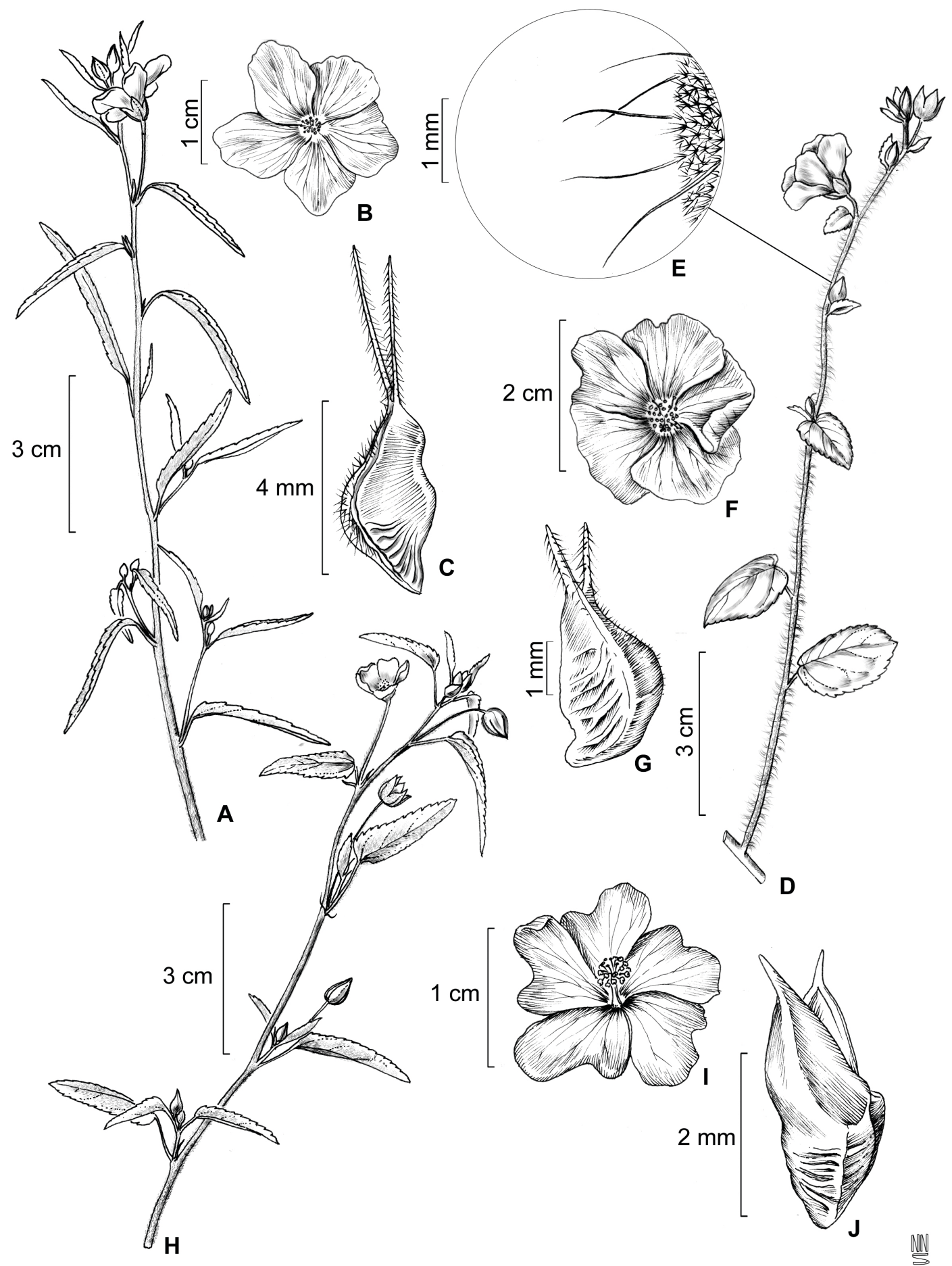

Figure 5. A-C. Sida angustissima. A. flowering branch; B. flower; C. mericarp. D-G. Sida galheirensis; D. flowering branch; E. detail of branch indumentum; F. flower; G. mericarp. H-J. Sida spinosa; H. flowering branch; I. flower; J. mericarp. A-C from J.B. Lima 57; D-G from A.S. Conceição 1288; H-J from J.B. Lima 80. 
In EPASB, Sida cordifolia occurs in open areas and along roadsides associated with sandy soils. It can be distinguished from all other congeners species by velutinous leaf and branches, leaf blades ovate with cordate base and mericarps $5 \mathrm{~mm}$ long, biaristate, arista parallel between them. It was collected with flowers and fruits during almost all year. The species has beekeeping, forage and medical potential (Sampaio et al. 2005).

11. Sida galheirensis Ulbr., Notizbl. Bot. Gart. Berlin-Dahlem 9: 40. 1924. Iconografia: Brandão (2014: 107). Figures 21; 31; 5d-g

Subshrubs $35-40 \mathrm{~cm}$ tall; branches hirsute, short stellate trichomes and simple longer. Stipules linear 3-5 mm long, trichomes stellate. Leaf with blade 1.5-4.5 × 1-3 cm, ovate to elliptical, discolorous, chartaceous, apex acute-acuminate, basis obtuse to subcordate, margin serrate, pubescent on both faces, trichomes stellate; petioles 9-11 mm long, hirsute, not spine. Flowers solitary, axillary or terminal. Pedicels $0.5-3 \mathrm{~cm}$ long; epicalyx absent; calyx 7-9 mm long, cupuliform, venation prominent, externally with stellate trichomes, internally trichomes only at the apex, lobes acute-acuminate at the apex; petals c. $1.5 \times 1.8 \mathrm{~cm}$, obovate, yellow-orange with red-vinaceous base, glabrous; stamens c. 50, staminal tube 2-3 mm long, free portion of the stamens $1.5-2 \mathrm{~mm}$ long, concentrated at the apex of the tube; ovary c. $1 \times 1$, subglobose, glabrous, carpels 7-8, uniovulate, styles 7-8, 4-5 mm long. Schizocarp not inflated; mericarps $7-8$, c. $3 \times 3 \mathrm{~mm}$, shortly biaristate, arista divergent, simple retrorse trichomes, white, lateral face reticulated, resistant; seeds 1 per mericarp c. $2 \times 1 \mathrm{~mm}$, reniform, brown, glabrous.

Material examined: APA Serra Branca, Base da vaca morta, 955'17,2"S 38 42'06”'W, 392 m, 10.VII.2012, bot.; fl., J.B. Lima 35 (HUNEB); Estrada principal sentido Serra do Navio, 953'37.2”S 3840'29.2”W, 429 m, 10.VII.2012, bot.; fl.; fr., J.B. Lima 36 (HUNEB); trilha da Serra do Morro. 952'49”'S 38³9'22”'W, 481 m, 30.VII.2009, fl., T.M.S. Melo 52 (HUNEB); $1 \mathrm{~km}$ da base da base da vaca morta, 954'23”'S $38^{\circ} 41^{\prime} 22^{\prime}$ 'W, 367 m, 17.IV.2008, fl., A.S. Conceição 1288 (HUNEB); 1 km da Vaca Morta, 953'17.3"'S 3840'10.5”W, 384 m, 17.IV.2008, fl., A.S. Conceição 1293 (HUNEB).

Sida galheirensis is endemic from Northeastern Region of Brazil, and is found in the states of Alagoas, Bahia, Ceará, Maranhão, Paraíba, Pernambuco, Piauí and Rio Grande do Norte, in Caatinga and Cerrado environments (Bovini 2016d).

It is recognized by flowers with yellow-orange petals, a red-vinaceous base and mericarps 7-8-mm long, shortly biaristate with divergent arista. In the EPASB, S. galheirensis is widely distributed in the undergrowth and shrub borders on sandy soils. It blooms during almost the entire year and fruits in May and July. Reported by Sampaio et al. (2005) as a species for beekeeping and forage.

12. Sida linifolia Cav., Diss. 1: 14. 1785. Iconografia: Schumann (1891: 57), Rondón (2009: 615), Brandão (2014: 109). Figure 2m

Subshrubs 50-60 cm tall; branches hirsute, trichomes simple, rare fasciculate. Stipules linear 4-5 mm long, simple trichomes. Leaf with blade $3.5-7 \times 0.2-1.5 \mathrm{~cm}$, linear to narrow elliptic, discolorous, chartaceous, apex acute-acuminate, basis obtuse, margin entire, trinerve, pubescent on both faces, trichomes simple; petioles 4-10 mm long, not spine. Inflorescences corymb, terminal. Flowers pedicels $0.5-1 \mathrm{~cm}$ long; epicalyx absent; calyx 5-6 mm long, cupuliform, venation prominent, externally with simple trichomes, internally trichomes only at the apex, lobes acute-cuspidate at the apex; petals c. $0.8 \times 1.2 \mathrm{~cm}$, obovate, white with vinaceous basal spot, glabrous; stamens c. 40, staminal tube 2-3 mm long, free portion of the stamens c. $1 \mathrm{~mm}$ long, concentrated at the apex of the tube; ovary c. $1 \times 1$, subglobose, glabrous, carpels 8 , uniovulate, styles $8,3-4 \mathrm{~mm}$ long. Schizocarp not inflated; mericarps 8 , c. $3 \times 2.5 \mathrm{~mm}$, muticous, glabrous, lateral face reticulate, resistant; seeds 1 per mericarp, c. $2 \times 1 \mathrm{~mm}$, subreniforms, light brown, simple trichomes around at the hilum.
Material examined: APA Serra Branca, Baixa grande após o povoado Quelés, roça de Mané de Chico, 958'30.7'S 38²7’01'W, 564 m, 03.IX.2012, fl., J.B. Lima 55 (HUNEB).

A widely distributed species, it has been reported from America and Tropical Africa. In Brazil it occurs in all regions in Caatinga, Cerrado, Amazon Rainforest, Atlantic Forest and swamp environments. In the Northeast Region it occurs in the states of Bahia, Paraíba, Pernambuco, Piauí and Rio Grande do Norte (Bovini 2016d).

The species can be confused with $S$. angustissima (see comments in S. angustissima). However, it is recognized by its linear to narrow-elliptic leaves trinerved, entire margin, white petals with a vinaceous basal spot and, muticous and glabrous mericarps. In the EPASB, this species was collected only once with flowers and fruits in the rainy season. Sida linifolia has beekeeping potential (Sampaio et al. 2005).

13. Sida spinosa L., Sp. Pl. 2: 683. 1753. Iconografia: Rondón (2009: 616), Brandão (2014: 113). Figures 2n; $3 \mathrm{~h} ; 5 \mathrm{~h}-\mathrm{j}$

Subshrubs $25-30 \mathrm{~cm}$ tall; branches pubescent, trichomes stellate. Stipules linear 2-3 mm long. Leaf with blade $0.8-1.1 \times 0.3-0.6 \mathrm{~cm}$, narrow elliptic to elliptic, discolorous, chartaceous, apex acuminate, basis obtuse, margin serrate, pubescent on both faces, trichomes stellate; petioles 5-8 $\mathrm{mm}$ long, pubescent, with a purple spine. Flowers solitary, axillary or terminal; pedicels $0.5-1.5 \mathrm{~cm}$ long; epicalyx absent; calyx 4-5 mm long, cupuliform, venation prominent, externally with stellate trichomes, internally trichomes only at the apex, lobes acute to acuminate at the apex; petals $6-7 \times$ c. $9 \mathrm{~mm}$, obovate, white with yellow basal spot, glabrous; stamens c. 27 , staminal tube 2-4 mm long, free portion of the stamens 0.8-1 mm long, concentrated at the apex of the tube; ovary c. $1.2 \times 1.8 \mathrm{~mm}$, subglobose, glabrous, carpels 5, uniovulate, styles 5, 2-2.5 mm long. Schizocarp not inflated; mericarps 5 , c. $3.5 \times 2 \mathrm{~mm}$, biaristate, simple trichomes white, lateral face reticulated, resistant; seeds 1 per mericarp c. $1 \times 1.5 \mathrm{~mm}$, reniform, brown, glabrous.

Material examined: APA Serra Branca, Caminho da judite próximo a Serra do Navio, 951'55.5'S 38³8'45”'W, 469 m, 03.XI.2011, fl.; fr., J.B. Lima 01 (HUNEB).

A species widely distributed in the New World, and with few records in the Old World. In Brazil it is well represented in the Northeast Region (Bahia, Ceará, Paraíba, Pernambuco and Rio Grande do Norte), in areas of Caatinga, Cerrado and Atlantic Forest. The species does not occur in the Northern Region (Bovini 2016d).

In the EPASB, Sida spinosa is the only species of the genus with white petals with a yellow basal spot and only 5 mericarps. It was collected once with flowers and fruits in November on sandy-clayey soils. It is a species that holds medicinal and beekeeping potential (Sampaio et al. 2005).

14. Sidastrum micranthum (A.St.-Hil.) Fryxell, Brittonia 30(4): 452 (1978). Iconografia: Schumann (1891: 59), Rondón (2009: 618), Bovini (2010: 295). Figures 2o; $3 \mathrm{~m}$

Subshrub 45-50 cm tall; branches pubescent to tomentose, trichomes stellate. Stipules linear 5-7 mm long. Leaf with blade $2-6 \times 1.5-5 \mathrm{~cm}$, ovate, discolorous, chartaceous, apex acute, basis obtuse to cordate, margin crenate, velutinous on both faces, trichomes stellate; petiole $0.5-3 \mathrm{~cm}$ long, tomentose, not spine. Inflorescences glomeruliform, dense, axillary and terminal. Flowers subsessile or pedicels $0.5-1.5 \mathrm{~mm}$ long; epicalyx absent; calyx 2-3 mm long, cupuliform, not prominent venation, externally with stellate trichomes, internally simple trichomes on the apex, lobes acute; petals c. $4 \times 2 \mathrm{~mm}$, obovate, clear yellow with pink basal spot, glabrous; stamens c. 19, staminal tube c. $2 \mathrm{~mm}$ long, glabrous, free portion of the stamens $0.8-1 \mathrm{~mm}$ long, concentrated at the apex of the tube; ovary c. $1 \times 1 \mathrm{~mm}$, subglobose, simple trichomes on the apex, carpels 5, uniovulate, styles 5, 2-3 mm long, stigmas capitate. Schizocarp not inflated; mericarps $5,2-3 \times$ c. $2 \mathrm{~mm}$, muticous, pubescent, stellate trichomes white, lateral face lightly reticulate, fragile; seeds 1 per mericarp c. $1 \times 1 \mathrm{~mm}$, ovate, brown, glabrous. 
Material examined: APA Serra Branca, Baixa Grande, roça de Mané de Chico, 958'30.7’S 38²7’01’W, 564 m, 26.III.2013, bot.; fl.; fr., J.V. dos Santos 67 (HUNEB).

This species is distributed in the Neotropics (Fryxell 1997), in Brazil it is spread-out over the midwest (Goiás), northeast (Bahia, Ceará, Paraíba), southeast (Minas Gerais, São Paulo, Rio de Janeiro) and south (Paraná), and is found in the phytogeographical domains of Caatinga, Cerrado and Atlantic Forest (Bovini 2016e).

In the study area, $S$. micranthum can be distinguished by its dense glomerule inflorescences, shortly pedicellate small flowers and clear yellow petals with a pink basal spot. It was collected just once with flowers and fruits in March. The species holds medicinal potential (Sampaio et al. 2005).
15. Sidastrum multiflorum (Jacq.) Fryxell, Brittonia 31(2): 298. 1979. Figures 2p; 6a-d

Subshrub 25-30 cm tall; branches tomentose, trichomes stellate. Stipules linear 3-4 mm long. Leaf with blade 1.5-4 × 0.6-1.8 cm, ovate to elliptical, discolorous, chartaceous, apex acute to acuminate, basis obtuse, margin serrate, tomentose on both faces, trichomes stellate; petioles 1-4 mm long, pubescent, not spine. Inflorescences glomerule or flowers solitary, axillary; pedicels 1.5-3 mm long; epicalyx absent; calyx 4-5 mm, cupuliform, not prominent venation, externally with stellate trichomes, internally simple trichomes only at the apex, lobes acute at the apex; petals 6-7 $\times 5-6 \mathrm{~mm}$, obovate, yellow, trichomes simple at the base; stamens c. 20 , staminal tube 2-3 mm long, glabrous, free portion of the stamens 1-2 mm long,

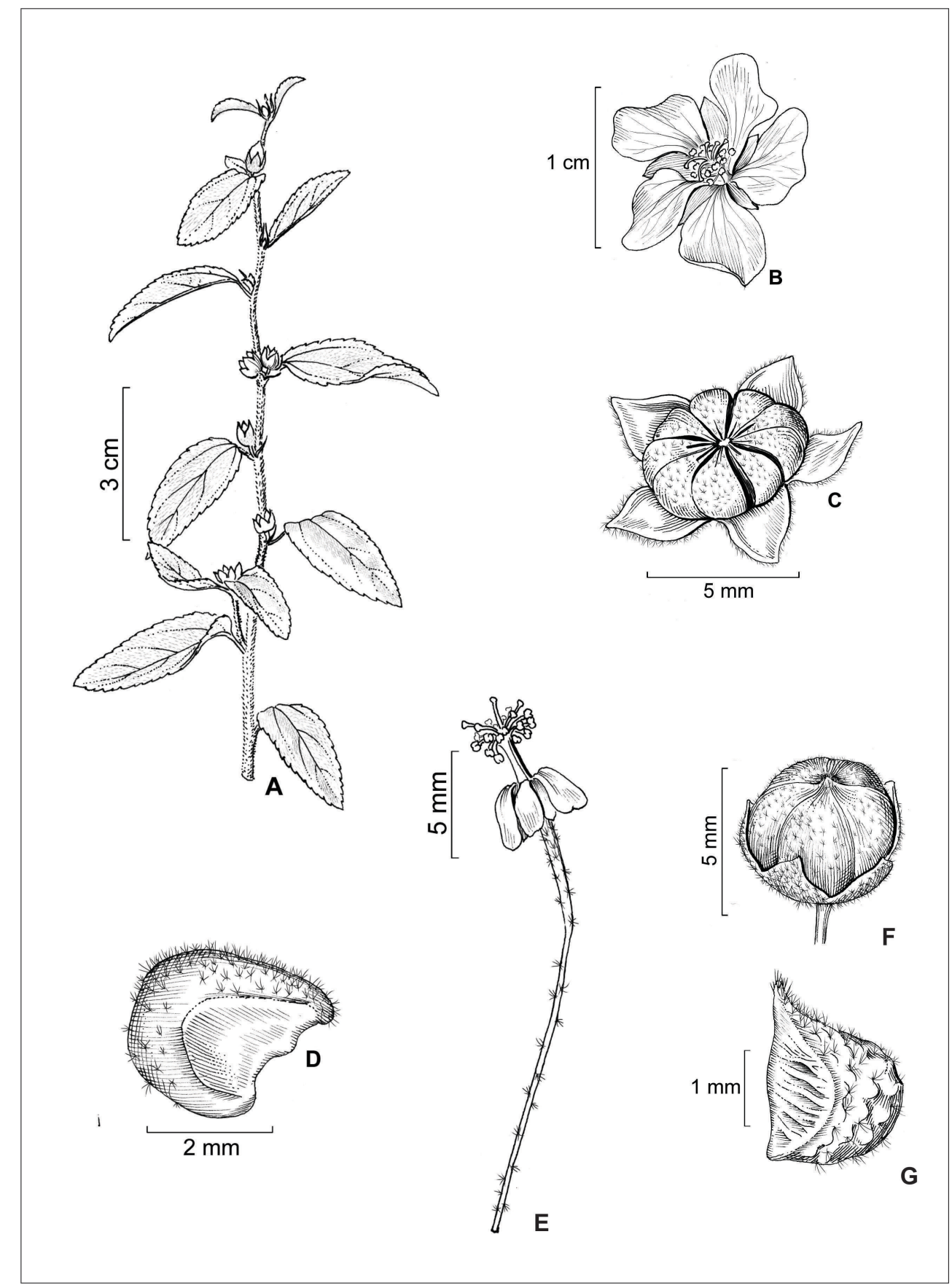

Figure 6. A-D. Sidastrum multiflorum; A. flowering branch; B. flower; C. fruit; D. mericarp. E-G. Sidastrum paniculatum; E. flower; F. fruit; G. mericarp. A-D from J.B. Lima 34; E-G. J.B from Lima 86. 
concentrated at the apex of the tube; ovary c. $1 \times 1.5 \mathrm{~mm}$, subglobose, glabrous, carpels 10, uniovulate, styles 10, 4-5 mm long, stigmas capitate. Schizocarp not inflated; mericarps 10, 2-3 mm long, muticous, stellate trichomes white, lateral face lightly reticulate, fragile; seeds 1 per mericarp c. $1.8 \times 1.5 \mathrm{~mm}$, reniform, nigrescent, slightly pilose.

Material examined: APA Serra Branca, Caminho da Judite próximo a Serra do Navio, 9'51'55.5'S 38 38'45'"W, 469 m, 03.XI.2011, fl.; fr., J.B. Lima 06 (HUNEB); Base da Vaca Morta, 955'17,2”S 3842’06”W, 392 m, 10.VII.2012, bot.; fl.; fr., J.B. Lima 34 (HUNEB); Baixa Grande, após o povoado Quelés, roça de Mané de Chico, 958'30.7'S 38²7'01'W, 564 m, 26.III.2013, fr., J.B. Lima 75 (HUNEB); Vaca Morta. 954’03”'S 3840'58”W, 386 m, 22.VIII.2008, fl., M.V. Romão 285 (HUNEB).

Sidastrum multiflorum occurs in the Bahamas, Cuba, Spain and the Antilles south to Argentina (Fryxell 1978, 1979). In Brazil it occurs in the northeast (Bahia, Maranhão, Paraíba, Pernambuco) and southeast (Espírito Santo) of the country in phytogeographic domains of Caatinga, Amazon Rainforest and Atlantic Forest (Bovini 2016e).

In the study area, it differs from its congeners by yellow petals that are more than $5 \mathrm{~mm}$ long and twice the number of mericarps (10). Specimens were collected with flowers in March, August, September and November and fruits in September and November in hyperxerophytic environments of Caatinga vegetation and in areas of contact with seasonal Caatingaforest on sandy soils.

16. Sidastrum paniculatum (L.) Fryxell, Brittonia 30(4): 453. 1978. Iconografia: Schumann (1891: 58). Figures 2q; 6e-g

Subshrub 50-70 cm tall; branches pubescent, trichomes stellate. Stipules linear 3-6 mm long. Leaf with blade 1.3-3 $\times 0.9-2 \mathrm{~cm}$, ovate to elliptical, discolorous, chartaceous, apex acute, basis obtuse to subcordate, margin serrate, pubescent on both faces, trichomes stellate; petioles $2-5 \mathrm{~mm}$ long, pubescent, not spine. Inflorescences paniculate, axillary and terminal; pedicels 1.5-2 cm long; epicalyx absent; calyx 2-3 mm long, cupuliform, not prominent venation, externally with stellate trichomes, internally simple trichomes on the apex, lobes acute at the apex; petals $4-5 \times 2.5-4 \mathrm{~mm}$, obovate, vinaceous, glabrous; stamens c. 20 , staminal tube $2-3 \mathrm{~mm}$ long, free portion of the stamens 1-2 mm long, concentrated at the apex of the tube; ovary c. $1 \times 1 \mathrm{~mm}$, globose, simple trichomes at the apex, carpels 5 , uniovulate, styles 5, 4-5 mm long., stigmas capitate. Schizocarp not inflated; mericarps 5, 3-5 mm long, muticous, pubescent, stellate trichomes white, lateral face lightly reticulate, fragile; seeds 1 per mericarp c. $1 \times 1 \mathrm{~mm}$, subglobose, brown, glabrous.

Material examined: APA Serra Branca, Caminho da Judite próximo a Serra do Navio, 951'55.5”S 38³8'45”'W, 469 m, 03.XI.2011, fl.; fr., J.B. Lima 08 (HUNEB); Serra do Navio, próximo ao barreiro, 951'56”'S 38³8'45”W, 479 m, 10.VII.2012, fl.; fr., J.V. dos Santos 40 (HUNEB).

Sidastrum paniculatum is a species with a Neotropical distribution (Wagner et al. 1999). In Brazil it has been recorded in the northeast (Bahia, Pernambuco, Paraíba), midwest (Mato Grosso do Sul, Mato Grosso) and southeast (Minas Gerais, Rio de Janeiro, São Paulo), in Caatinga, Cerrado, Amazon Rainforest and Atlantic Forest environments (Bovini, 2016e).

In the study area, it differs from its congeners by paniculate inflorescences with very small flowers (until $5 \mathrm{~mm}$ ) with long pedicels and vinaceous petals. In the EPASB it was found in edge shrubby-arborescent Caatinga on sandy and sandy-clayey soils. Specimens were collected with flowers and fruits in July and November. The species holds beekeeping potential (Sampaio et al. 2005)

\section{Appendix}

\section{List of additional material examined}

Bandeira, F.P. 154 (11); Bandeira, F.P. 91 (2); Cardoso, D. 955 (4); Carneiro-Torres, D.S. 512 (3); Carvalho-Sobrinho, J.G. de 563 (1); Castro, M.S de s/n (1); Castro, M.S. de s/n (11); Castro, M.S. de s/n (6); Castro, M.S. de s/n (8); Castro, R.M. 1274 (1); Colaço, M. 70 (2);
Conceição, A.A. 3022 (11); Conceição, S.F. 500 (15); Esteves, G.L. 2500 (1); Esteves, G.L. 2503 (6); Esteves, G.L. 2505 (2); Esteves, G.L. 2507 (14); Esteves, G.L. 2509 (6); Gomes, F.S. 184 (4); Leal, S. 42 (5); Lima, L.C.L. 179 (14); Melo, E. 10675 (11); Melo, E. 6430 (13); Melo, E. 6658 (11); Melo, E. 6711 (1); Melo, E. 6712 (5); Melo, E. 6713 (12); Melo, E. 6716 (10); Melo, E. 6776 (1); Melo, E. 6780 (8); Melo, E. 6801 (10); Miranda, E.B. 812 (11); Miranda, E.B. 820 (6); Miranda, E.B. 859 (2); Moraes, A.O. 88 (5).

Moraes, A.O. 91 (11); Noblick, L.R. 2950 (16); Pedreira, E.M. 19 (15); Pinto, G. 49 (3); Queiroz, L.P. de 435 (6); Queiroz, L.P. de 6562 (6); Queiroz, L.P. de 7164 (6); Queiroz, L.P. de 7210 (11); Queiroz, L.P. de 7260 (2); Queiroz, L.P. de 9036 (16); Rodarte, A. 03 (11).

\section{Acknowledgements}

Thanks to the Fundação de Amparo à Pesquisa do Estado da Bahia (FAPESB, PET \# 0023/2007) and to the Conselho Nacional de Desenvolvimento Científico e Tecnológico (CNPq Proc. \# 552589/2011-0) for financial support. To Companhia Hidrelétrica do São Francisco (CHESF) for their support during field work. To Gerleni Lopes Esteves by confirmation of the identities of the species. To anonymous reviewer by improvements. The first author thanks the FAPESB for the scholarship (BOL \# 1772/2011), the curators and technicians of the herbaria that were visited for their readiness during the consultation of the collections and Natanael Santos for the botanical illustrations.

\section{References}

ALVERSON, W.S., WHITLOCK, B.A., NYFFLER, R., BAYER, C. \& BAUM, D.A. 1999. Phylogeny of the core Malvales: evidence from $n d h \mathrm{~F}$ sequence data. Amer. J. Bot. 86(10):1774-1486

ALVES, I.M., DANTAS, I.C., MELO, J.I.M., FELISMINO, D.C. 2011. A Família Malvaceae sensu lato em uma área do Agreste Paraibano, Nordeste do Brasil. BioFar. 06(01):1-20.

AMORIM, B.S., SAUNDERS, J.G., DU BOCAGE NETA, A.L. \& ALVES, M 2009. Malvaceae s.l. In Flora de Mirandiba. (M. Alves, M.F. Araujo, J.R. Maciel, S. Martins, eds). Associação Plantas do Nordeste, Recife. p.245-262.

BAUM, D.A., SMITH, S.D., YEN, A., ALVERSTON, W.S., NYFELER, R., WHITLOCK, A. \& OLDHAM, R. 2004. Phylogenetic relationship of Malvatheca (Bombacoideae and Malvoideae; Malvaceae sensu lato) as inferred from plastid DNA sequences. Am. J. Bot. 91(11):1863-1871.

BAYER, C., FAY, M.F., DE BRUIJIN, A.Y., SAVOLAINEN, V., MORTON, C.M., KUBITZKI, K., ALVERSON, W.S. \& CHASE, M.W. 1999. Support for an expanded family concept of Malvaceae within a recircunscribed order Malvales: a combined analysis of plastid $a t p \mathrm{~B}$ and $r b c \mathrm{~L}$ DNA sequences. Bot. J. Linn. Soc. 129 (4):267-303

BAYER, C. \& KUBITZKI, K. 2003. Malvaceae. In The families and Genera of Vascular Plants. Flowering Plants Dicotyledons. Malvales, Capparales and Non-betalain Caryophyllales. (K. Kubitzky \& C. Bayer, eds). Springer-Verlag, Berlin. v.5, p.225-311.

BOVINI, M.G., CARVALHO-OKANO, R.M. \& VIEIRA, M.F. 2001. Malvaceae A. Juss. no Parque Estadual do Rio Doce, Minas Gerais, Brasil. Rodriguésia 52(81):17-47.

BOVINI, M.G., ESTEVES, G.L. \& DUARTE, M.C. 2010. Malvaceae. In Catálogo de Plantas e Fungos do Brasil. (R.C. Forzza, P.M. Leitman, A. Costa, A.A.C. Junior, A.L. Peixoto, B.M.T. Walter, C. Bicudo, D. Zappi, D.P. Costa, E. Lleras, G. Martinelli, H.C. Lima, J. Prado, J.R. Stehmann, J.F.A. Baumgratz, J.R. Pirani, L.S. Sylvestre, L.C. Maia, L.G. Lohmann, L.P. Queiroz, M. Silveira, M. Nadruz, M.C.H. Mamede, M.N.C. Bastos, M.P. Morim, M.R. Barbosa, M. Menezes, M. Hopkins, R. Secco, T. Cavalcanti, V.C. Souza, orgs). Jardim Botânico do Rio de Janeiro, Rio de Janeiro, v.2, p.1201-1227.

BOVINI, M.G., ESTEVES, G., DUARTE, M.C., TAKEUCHI, C., KUNTZ, J. 2016. Malvaceae. In Lista de Espécies da Flora do Brasil. Jardim Botânico do 
Rio de Janeiro. http://floradobrasil.jbrj.gov.br/jabot/floradobrasil/FB156 (last access in 22/01/2016).

BOVINI, M.G. 2008. Revisão taxonômica do gênero Wissadula Medik. (Malvoideae, Malvaceae) no Brasil. Tese de doutorado, Universidade Federal do Rio de Janeiro, Museu Nacional, Rio de Janeiro.

BOVINI, M.G. 2010. Malvaceae s. str. na Reserva Rio das Pedras, Mangaratiba, Rio de Janeiro, Brasil. Rodriguésia 61(2):289-301.

BOVINI, M. 2016a. Herissantia. In Lista de Espécies da Flora do Brasil. Jardim Botânico do Rio de Janeiro. http://floradobrasil.jbrj.gov.br/jabot/floradobrasil/ FB19521 (last access in 12/02/2016).

BOVINI, M. 2016b. Malvastrum. In Lista de Espécies da Flora do Brasil. Jardim Botânico do Rio de Janeiro. http://floradobrasil.jbrj.gov.br/jabot/floradobrasil/ FB19521 (last access in 12/02/2016).

BOVINI, M.G. 2016c. Pseudabutilon. In Lista de Espécies da Flora do Brasil. Jardim Botânico do Rio de Janeiro. http://floradobrasil.jbrj.gov.br/jabot/floradobrasil/ FB19521 (last access in 12/02/2016)

BOVINI, M.G. 2016d. Sida. In Lista de Espécies da Flora do Brasil. Jardim Botânico do Rio de Janeiro. http://floradobrasil.jbrj.gov.br/jabot/floradobrasil/FB19521 (last access in 12/02/2016).

BOVINI, M.G. 2016e. Sidastrum. In Lista de Espécies da Flora do Brasil. Jardim Botânico do Rio de Janeiro. http://floradobrasil.jbrj.gov.br/jabot/floradobrasil/ FB19521 (last access in 12/02/2016).

BRANDÃO, J.L. 2014. O Gênero Sida L. (Malvaceae) no estado de Pernambuco, Brasil. Dissertação de mestrado, Universidade Federal Rural de Pernambuco, Recife.

CRONQUIST, A. 1981. An integrated system of classification of flowing plants. Columbia University Press, New York.

CRONQUIST, A. 1988. The evolution and classification of flowing plants. The New York Botanical Garden, New York.

DAHLGREN, R.M.T. 1980. A revised system of classification of angiospems. Botanical Journal of Linnean Society 80(2):91-124.

ESTEVES, G.L. 1986. A ordem Malvales na Serra do Cipó, Minas Gerais, Brasil. Dissertação de mestrado, Universidade de São Paulo, São Paulo.

ESTEVES, G.L. 1998. O Gênero Pavonia Cav. (Malvaceae) na Região Nordeste do Brasil. Bol. Bot. Univ. São Paulo (11):161-235.

ESTEVES, G.L. 2001. O gênero Pavonia Cav. (Malvaceae) na Região Sudeste do Brasil. Bol. Bot. Univ. São Paulo (15):125-194.

ESTEVES, G.L. 2006. Flora da Reserva Ducke, Amazonas, Brasil: Malvaceae. Rodriguésia 57(2):205-206.

ESTEVES, G. 2016. Pavonia. In Lista de Espécies da Flora do Brasil. Jardim Botânico do Rio de Janeiro. http://floradobrasil.jbrj.gov.br/jabot/floradobrasil/ FB19521 (last access in 12/02/2016).

ESTEVES, G.L. \& KRAPOVICKAS, A. 2009. Flora de Grão-Mogol, Minas Gerais: Malvaceae. Bol. Bot. Univ. São Paulo 27(1):63-71.

FOSBERG, F.R. \& SACHET, M.H. 1965. Manual for tropical herbaria. Utrecht, Netherlands.

FRYXELL, P.A. 1973. New species and other notes in the Malvaceae. Brittonia 25:77-85.

FRYXELL, P.A. 1978. Neotropical Segregates From Sida L. (Malvaceae). Brittonia 30(4):447-462.

FRYXELL, P.A. 1979. The Genus Sidastrum E.G.BAKER (Malvaceae): a correction. Brittonia 31(2):298

FRYXELL, P.A. 1986. Malvaceae. In Florula of Mucugê, Chapada Diamantina, Bahia, Brazil (R.M. Harley \& N.A. Simmons, eds). Royal Botanical Gardens, Kew, p.132-133.

FRYXELL, P.A. 1988. Malvaceae of México. Systematic Botany Monographs. Michigan, v.25, p.1-522.

FRYXELL, P.A. 1995. Malvaceae. In Flora of the Pico das Almas, Chapada Diamantina, Bahia, Brazil (B. Stannard, org) Royal Botanical Gardens, Kew, p.430-432.

FRYXELL, P.A. 1997. The American genera of Malvaceae-II. Brittonia 49(2):204-69.

FRYXELL, P.A. 1999. Pavonia Cavanilles (Malvaceae). Flora Neotropica 76:1-284.

Fundação CTI/NE. 2016. http://www.ctinordestedobrasil.com.br/poligono.html (last access in 13/07/2016).
GONÇALVES, E.G. \& LORENZI, H. 2011. Morfologia vegetal: organografia e dicionário ilustrado de morfologia das plantas vasculares. 2 ed. Instituto Plantarum, São Paulo.

GRINGS, M. 2011. O gênero Pavonia Cav. (Malvaceae) no Rio Grande do Sul, Brasil. Dissertação de mestrado. Universidade Federal do Rio grande do Sul, Rio Grande do Sul, Brasil.

GÜRKE, M. 1892. Malvaceae II. In Flora Brasiliensis (C.P.F. Martius \& A.G. Eichler.). 12(3):98.

HARRIS, J. \& HARRIS, M. 2001. Plant identification terminology: an illustrated glossary. 2 ed. Spring Lake Publishing, Utah.

HILL, S.R. 1980. New taxa and combinations in Malvastrum A. GRAY (Malvaceae: Malveae). Brittonia 32(4):464-483.

JUDD, W.S. \& MANCHESTER, S.R. 1997. Circumscription of Malvaceae (Malvales) as determined by a preliminary cladistic analysis of morphological, anatomical, palynological, and chemical characters. Brittonia 49(3):384-405.

JUDD, W.S., CAMPBELL, C.S., KELLOG, E.E., STEVENS, P. \& DONOGHUE, M.J. 2009. Sistemática vegetal um enfoque filogenético. 3 ed. Artmed, Porto Alegre.

KRAPOVICKAS, A. 2007. Las especies de Sida secc. Malacroideae (Malvaceae) del cono Sur de Sudamérica. Bonplandia 16(3-4):209-253.

MONTEIRO FILHO, H. 1955. Malvaceae brasilienses novae vel criticae. I. Boletim da Sociedade Portuguesa de Ciencias Naturais 5:119-140.

MORI, S.A., SILVA, L.A.M., LISBOA, G. \& CORADIN, L. 1989. Manual de manejo do herbário fanerogâmico. Ilhéus: Centro de Pesquisa do Cacau.

NYFFELER, R., BAYER, C., ALVERSON, W.S., YEN, A., WHITLOCK, B.A., CHASE, M.W. \& BAUM, D.A. 2005. Phylogenetic analysis of the Malvadendrina clade (Malvaceae $s . l$.) based on plastid DNA sequences. Organisms, Diversity \& Evolution. 5:109-123.

ROBYNS, A. 1965. Malvaceae. In Flora do Panamá (R.E. Woodson et al.) Ann. Missouri Bot. Gard. v.52, p.497-577.

RONDÓN, J.B. 2009. La subfamilia Malvoideae (Malvaceae s.1.) en el occidente del estado Sucre, Venezuela. Revista UDO Agrícola 9(3):599-621.

SAMPAIO, E.V.S.B., PARYEN, F.G.C., FIGUEIRÔA, J.M. \& JUNIOR, A.G.S. 2005. Espécies da Flora Nordestina de Importância Econômica Potencial. Associação Plantas do Nordeste, Recife.

SCHUMANN, K. 1886. Tiliaceae, Sterculiaceae, Bombacaceae, Malvaceae. In Flora Brasiliensis (C.P.F. Martius \& A.G. Eichler) 12(3):50-57.

SCHUMANN, K. 1891. Malvaceae I. In Flora Brasiliensis (C.P.F. Martius \& A.G. Eichler) 12(3):253-456

SIQUEIRA FILHO, J.A., CONCEIÇÃO, A.A., RAPINI, A., COELHO, A.O.P., ZUNTINI, A.R., JOFFILY, A., VIEIRA, A.O.S., PRATA, A.P.N., MACHADO, A.F.P., ALVES-ARAÚJO, A.G., MELO, A.L., AMORIM, A.M.A., FONTANA, A.P., MOREIRA, A.D.R., LIMA, C.T., PROENÇA, C.E.B., LUZ, C.L., KAMEYAMA, C., CAIRES, C.S., BOVE, C.P., MYNSSEN, C.M., SÁ, C.F.C., MELO, E., SOUZA, E.B., LEME, E.M.C., FIRETTI-LEGGIERI, F., SALIMENA, F.R.G., FRANÇA, F., RAINER, H., FARIA, J.E.Q., MACIEL, J.R., LOPES, J.C., BRAGA, J.M.A., STEHMANN, J.R., JARDIM, J.G., PEREIRA, J.F., PASTORE, J.F.B., VALLS, J.F.M., DE MELO, J.I.M., PIRANI, J.R., SILVA, J.A., DE PAULA-SOUZA, J., CARDOSO, L.J.T., MATIAS, L.Q., LOHMANN, L.G., QUEIROZ, L.P., OLIVEIRA, M.A., SOBRAL, M.E.G., SILVA, M.J., MEIADO, M.V., COELHO, M.A.N., COSTA E SILVA, M.B., MAMEDE, M.C.H., LUCENA, M.F.A., PESSOA, M.C.R., LOIOLA, M.I.B., ARBO, M.M., BARBOSA, M.V.R., MARCHIORETTO, M.S., BURIL, M.T., BOVINI, M.G., BUENO, N.C., FIASCHI, P., BORGES, R.A.X., FORZZA, R.C., SEBASTIANI, R., MELLO-SILVA, R., COUTO, R.S., LIMA, R.B., PEREIRA, R.C.A., MARQUETE, R., BARRETO, R.C., XAVIER, S.R.S., PROFICE, S.R., CAVALCANTI, T.B., SILVA, T.R.S., POTT, V.J., KLEIN, V.L.G. \& SOUZA, V.C. 2012. Flora das caatingas do Rio São Francisco. In Flora das caatingas do Rio São Francisco: história natural e conservação (J.A. Siqueira Filho, org). Andrea Jakobsson Estúdio Editorial, Rio de Janeiro, p.446-552.

SOUZA, V.C. \& LORENZI, H. 2012. Botânica Sistemática: Guia ilustrado para identificação das famílias de Fanerógamas nativas e exóticas no Brasil, baseado em APG III. 3 ed. Instituto Plantarum, Nova Odessa.

SZABO, A.V., ROCHA, A.C.S., TOSATO, J.A. DE C. \& BARROSO, W. 2007. Área de proteção ambiental (APA) Serra Branca Raso da Catarina. In As Caatingas: 
debates sobre a ecorregião do Raso da Catarina (J. Marques, org.). Fonte Viva, Paulo Afonso. p.21-40.

TAKEUCHI, C. 2011. Estudo taxonômico de Abutilon Mill. (Malvoideae-Malvaceae) no Estado de São Paulo. Dissertação de mestrado, Instituto de Botânica da Secretaria de Estado do Meio Ambiente, São Paulo.

TAKEUCHI, C. \& ESTEVES, G.L. 2012. Synopsis of Abutilon (Malvoideae, Malvaceae) in the state of São Paulo, Brazil. Phytotaxa 44:39-57.

TAKHTAJAN, A.L. 1980. Outline of the classification of the flowering plants (Magnoliophyta). Botanical Review 46(3):225-359.

THIERS, B. 2016 [continuously updated]. Index Herbariorum: a global directory of public herbaria and associated staff. In New York Botanical Garden's Virtual Herbarium. http://sweetgum.nybg.org/ih/ (last access in 23/03/2016).

VARJÃO, R.R., JARDIM, J.G. \& CONCEICÃO, A.S. 2013. Rubiaceae Juss. de caatinga na APA Serra Branca/Raso da Catarina, Bahia, Brasil. Biota Neotropica 13(2): http://www.biotaneotropica.org.br/v13n2/en/abstract ?inventory+bn00313022013 (last access in 13/07/2016).

VELlOSO, A.L., SAMPAIO, E.V.S.B. \& PAREYN, F.G.C. 2002. Ecorregiões propostas para o bioma Caatinga. Associação Plantas do Nordeste, Recife.

VOGEL, S. 2000. The floral nectaries of Malvaceae sensu lato: a conspectus. Kurtziana 28:155-171.

WAGNER, W.L., HERBST, D.R. \& SOHMER, S.H. 1999. Manual of the flowering plants of Hawaii. Revised edition. Bernice P. Bishop Museum special publication. University of Hawaii Press/Bishop Museum Press, Honolulu.

Received: 01/04/2016

Revised: $12 / 08 / 2016$

Accepted: 28/09/2016 